\title{
Synthesis of nonracemic hydroxyglutamic acids
}

\author{
Dorota G. Piotrowska*, Iwona E. Głowacka*, Andrzej E. Wróblewski \\ and Liwia Lubowiecka
}

\author{
Review \\ Address: \\ Bioorganic Chemistry Laboratory, Faculty of Pharmacy, Medical \\ University of Lodz, Muszynskiego 1, 90-151 Lodz, Poland \\ Email: \\ Dorota G. Piotrowska* - dorota.piotrowska@umed.lodz.pl; \\ Iwona E. Głowacka* - iwona.glowacka@umed.lodz.pl \\ ${ }^{*}$ Corresponding author \\ Keywords: \\ amino acids; asymmetric synthesis; chiral catalysis; chiral pool; \\ glutamate analogues
}

\author{
Beilstein J. Org. Chem. 2019, 15, 236-255. \\ doi:10.3762/bjoc. 15.22 \\ Received: 11 September 2018 \\ Accepted: 22 December 2018 \\ Published: 25 January 2019 \\ Dedicated to Professor Michalska on the occasion of her 95th birthday. \\ Associate Editor: M. Rueping \\ (C) 2019 Piotrowska et al.; licensee Beilstein-Institut. \\ License and terms: see end of document.
}

\begin{abstract}
Glutamic acid is involved in several cellular processes though its role as the neurotransmitter is best recognized. For detailed studies of interactions with receptors a number of structural analogues of glutamic acid are required to map their active sides. This review article summarizes syntheses of nonracemic hydroxyglutamic acid analogues equipped with functional groups capable for the formation of additional hydrogen bonds, both as donors and acceptors. The majority of synthetic strategies starts from natural products and relies on application of chirons having the required configuration at the carbon atom bonded to nitrogen (e.g., serine, glutamic and pyroglutamic acids, proline and 4-hydroxyproline). Since various hydroxyglutamic acids were identified as components of complex natural products, syntheses of orthogonally protected derivatives of hydroxyglutamic acids are also covered.
\end{abstract}

\section{Introduction}

L-Glutamic acid (1, Figure 1) plays an important role in the biosynthesis of purine and pyrimidine nucleobases [1]. It also takes part in metabolic transformation to L-glutamine by L-glutamate synthetase (GS) which is crucial for cell maintenance.<smiles>N[C](CCC(=O)O)C(=O)O</smiles>

1

Figure 1: Structure of L-glutamic acid.
In neoplastic cells synthesis of L-glutamine is interfered as a result of reduced activity of GS [2]. $\gamma$-Glutamyl transpeptidase (GGT) which catalyses transfer of the $\gamma$-glutamyl group from glutathione is another enzyme relevant in cancer. High activities of GGT are observed during neoplastic transformation [3].

Several derivatives of L-glutamic acid functioning as anticancer agents have been reported [4]. But primarily L-glutamic acid is known as the major excitatory neurotransmitter in central nervous system which acts by binding to glutamate receptors [5-7]. However, these interactions are linked to several 
neurodegenerative diseases (Alzheimer [8], Huntington [9], Parkinson [10]) as well as to stroke [11] and epilepsy [12].

Two main classes of receptors, each of them containing three subclasses which are further divided into subtypes have been established for glutamic acid. To understand the physiological role of each receptor, recognition of their specific ligands is necessary. This, in turn, may pave a way for development of drug candidates for future therapeutic applications. These goals can be achieved by synthesis of glutamic acid analogues modifying the structure of $\mathbf{1}$ through installation of additional substituents, tuning the conformational flexibility of analogues and introducing groups capable of hydrogen bonding. Crystallographic data obtained for glutamate receptors [13-15] showed complex set of atoms interacting electrostatically and through hydrogen bonds and the conclusions from these studies should facilitate the development of new ligands.

In terms of mapping of glutamate receptors hydroxyglutamic acids 2-4 (Figure 2) should be of great interest since an additional hydroxy group is capable of acting as a hydrogen bond donor as well as a hydrogen bond acceptor. In fact $(2 S, 4 S)-\mathbf{3}$ showed similar potency at $\mathrm{mGlu}_{1 \mathrm{a}} \mathrm{R}$ and $\mathrm{mGlu}_{8 \mathrm{a}} \mathrm{R}$ as L-glutamic acid [16] while its affinity for AMPA and NMDA receptors was low [17]. On the other hand, $(2 S, 4 R)$-3 demonstrated significant preference for the NMDA receptor [17] Furthermore, it was found that $(2 S, 3 S, 4 S)-\mathbf{4}$ acts as a selective agonist of mGluR1 and as a weak antagonist of mGluR4 [18] Excitatory amino acid transporters (EAAT) are effected by hydroxyglutamic acid in various degrees. For example, $(2 S, 4 S)$ 3 appeared to be a substrate at EAAT1-3, while $(2 S, 4 R)-3$ did not interact with them $[19,20]$. A number of studies revealed that several giant neurons of the African giant snail appeared to be sensitive to various extents to all stereoisomers of 2 [21-23].

Hydroxyglutamic acids are widely spread in nature, especially in plants but they were also found in other species or as components of more complex molecules of interesting biological activity. Indeed, the interest in 3-hydroxyglutamic acid started many years ago by the discovery of this amino acid in hydrolysates of an antibiotic peptide S-520 [24]. It has been proved recently that it was actually the isomer $(2 S, 3 R)-\mathbf{2}$ and it is a fragment of a cyclohexapeptide [25]. $(2 R, 3 S)-2$ and $(2 R, 3 R)-\mathbf{2}$ were found as components of antifungal and antimicrobial hexadepsipeptides called kutznerides isolated from the actinomycete Kutzneria sp. 744 [26,27]. And finally, threo-3hydroxyglutamic acid was identified in the cell wall of Mycobacterium lacticum [28].

4-Hydroxy-L-glutamic acid [(2S,4S)-3] was found in several plants, e.g., Phlox decussata [29] and other Phlox species [30], as well as in Linaria vulgaris [31]. It has also been discovered in mammalian cells as an intermediate in the degradation of hydroxyproline [32,33]. Its various amides have been identified in numerous plants [34-39] as well as components of complex molecules produced by different species [40-42]. 3,4-Dihydroxyglutamic acid (4) of unknown stereochemistry was identified as a constituent of seeds of Lepidum sativum and leaves of Rheum rhaponticum and later on in other species [43,44].

Natural occurrence as well as possibilities of glutamate-like biological activity modulated by additional hydrogen bonding with hydroxy groups inspired the interest in the synthesis of stereoisomers of hydroxyglutamic acids 2-4 (Figure 2). Since they contain two or three stereogenic centers their orthogonally protected derivatives could be considered as extremely valuable chirons in syntheses of various natural products. Their 1,2- and 1,3-aminohydroxy fragments can serve as pharmacophores of interest in medicinal chemistry. In this paper we wish to review chemical syntheses of non-racemic 3-hydroxy- (2), 4-hydroxy(3) and 3,4-dihydroxyglutamic acid (4) to summarize achievements in this area. The protected forms of 3-hydroxyglutamic acid are of significant value as intermediates in the synthesis of complex peptides.

\section{Review \\ 3-Hydroxyglutamic acid}

The reports on the optical resolution and characterization of four enantiomers 2 (Figure 3) came from the Japanese sources [45-48]. For identification purposes $\left(2 S^{*}, 3 R^{*}\right)-2$ and $\left(2 S^{*}, 3 S^{*}\right)-2$ were resolved by chiral reversed-phase TLC [26]. Kinetic resolution of dibenzyl $\left(2 S^{*}, 3 R^{*}\right)$ - $N$-Boc-3-hydroxyglutamate was achieved in the presence of Subtilisin Carlsberg to give dibenzyl $(2 R, 3 S)$ - $N$-Boc-3-hydroxyglutamate and $(2 S, 3 R)$ -<smiles>NC(C(=O)O)C(O)CC(=O)O</smiles>

2<smiles>NC(CC(O)C(=O)O)C(=O)O</smiles>

3<smiles>NC(C(=O)O)C(O)C(O)C(=O)O</smiles>

4

Figure 2: 3-Hydroxy- (2), 4-hydroxy- (3) and 3,4-dihydroxyglutamic acids (4). 
<smiles>NC(CC(=O)O)C(O)C(=O)O</smiles>

$(2 S, 3 R)-2$<smiles>NC(CC(=O)O)C(O)C(=O)O</smiles>

$(2 R, 3 S)-2$<smiles>NC(CC(=O)O)C(O)C(=O)O</smiles>

$(2 S, 3 S)-2$<smiles>N[C@@H](CC(=O)O)C(O)C(=O)O</smiles>

$(2 R, 3 R)-2$

Figure 3: Enantiomers of 3-hydroxyglutamic acid (2)

5-(benzyloxy)-2-[(tert-butoxycarbonyl)amino]-3-hydroxy-5oxopentanoic acid [25].

The majority of asymmetric syntheses of 3-hydroxyglutamic acid employ serine or similar three-carbon chirons as starting materials. Configuration at $\mathrm{C} \alpha$ is retained in the final products and it also induces chirality at the $\mathrm{C} \beta(\mathrm{OH})$ center. The hydroxymethyl group of serine can serve as a precursor of the carboxyl fragment but when oxidized to aldehyde it may be attacked by nucleophiles to introduce the required two-carbon residue.

\section{From serine-derived precursors}

When Garner's aldehyde $(R)-5$ prepared from D-serine was subjected to $\mathrm{ZnCl}_{2}$-catalyzed cyclocondensation with Danishefsky's diene a $(>9: 1)$ mixture of diastereoisomeric pyranones 6 was formed with the threo isomer 6a prevailing. Oxidative removal of two carbon atoms was followed by formate hydrolysis, formation of methyl ester and silylation to give 7 after separation from the minor diastereoisomer. After selective hydrolysis of the acetal the hydroxymethyl fragment was oxidized and all protective groups were removed to give $(2 S, 3 R)-\mathbf{2}$ as the hydrochloride (Scheme 1). The observed stereoselectivity of the cyclocondensation step is best explained by the attack on a re-face of the $\mathrm{C}=\mathrm{O}$ group due to chelation of $\mathrm{Zn}^{2+}$ to the carbonyl oxygen and amide nitrogen/oxygen atoms [49].

A better approach in terms of carbon atom economy relied on the addition of allylmagnesium chloride to the aldehyde $(R)-\mathbf{5}$ which after O-benzylation provided an inseparable 1:3 mixture of compounds 8a and $\mathbf{8 b}$. A six-carbon chain was shortened by a diol formation-diol cleavage sequence followed by aldehyde oxidation and esterification to give $\mathbf{9 a}$ and $\mathbf{9 b}$ after chromato- graphic separation. They were transformed into $(2 S, 3 R)-\mathbf{2}$ and $(2 S, 3 S)-2$ in several steps including hydroxymethyl to carboxyl oxidations (Scheme 2) [50].

$\mathrm{N}$-Fmoc protection of the amino group in L-serine together with transformation of the carboxylic function into an orthoester allow for the racemization-free oxidation to aldehyde 10, which was immediately subjected to Reformatsky reaction to give a 92:8 mixture of $(2 S, 3 R)-\mathbf{1 1}$ and $(2 S, 3 S)$-11, respectively. The major diastereoisomer was formed by the attack on the re-face of the carbonyl group in accordance with the non-chelation Felkin-Ahn model 12 in which the largest substituent at $\mathrm{C} \alpha$ (orthoester) is positioned opposite to the incoming nucleophile. After removal of protective groups with iodotrimethylsilane 3-hydroxyglutamic acid (2) was obtained as the monoammonium salt $[(2 S, 3 R):(2 S, 3 S), 94: 6]$ or the hydrochloride [(2S,3R):(2S,3S), >98:2] (Scheme 3) [51].

Treatment of a trilithium salt of the N-protected acid $\mathbf{1 3}$ derived from L-serine with allylmagnesium bromide provided ketone $\mathbf{1 4}$ which was reduced to diastereoisomeric diols in a 9:1 syn to anti ratio when L-selectride was applied. They were separated as isopropylidene derivatives and the syn isomer $\mathbf{1 5}$ was subjected to ozonolysis and oxidation to give acid 16. To complete the synthesis of di-tert-butyl ester of $(2 R, 3 S)$-2 compound $\mathbf{1 6}$ was first transformed into the ester and later deprotected to the diol 17 which was selectively oxidized, again esterified and finally the phenylsulfonyl group was removed electrochemically (Scheme 4) [52].

The aldehyde $(S)$-18 prepared from $O$-benzyl-L-serine in three standard steps [53] was elongated by a two-carbon fragment<smiles>CC(C)(C)OC(=O)N1C(C=O)COC1(C)C</smiles>

$(R)-5$<smiles>CC(C)(C)OC(=O)N1C([C@@H]2CC(=O)C=CO2)COC1(C)C</smiles>

$6 a$<smiles>COC(=O)C[C@H](O[Na])C1COC(C)(C)N1C(=O)OC(C)(C)C</smiles>

7<smiles>N[C](C(=O)O)[C@@H](O)CC(=O)O</smiles>

$(2 S, 3 R)-2$ 
<smiles>CC(C)(C)OC(=O)N1C(C=O)COC1(C)C</smiles>

(R)-5<smiles>C1CCCCC1</smiles><smiles>C=CC[C@@H](OCc1ccccc1)C1COC(C)(C)N1C(=O)OC(C)(C)C</smiles>

$8 a$<smiles>C=CC[C@@H](OCc1ccccc1)C1COC(C)(C)N1C(=O)OC(C)(C)C</smiles>

$8 b$

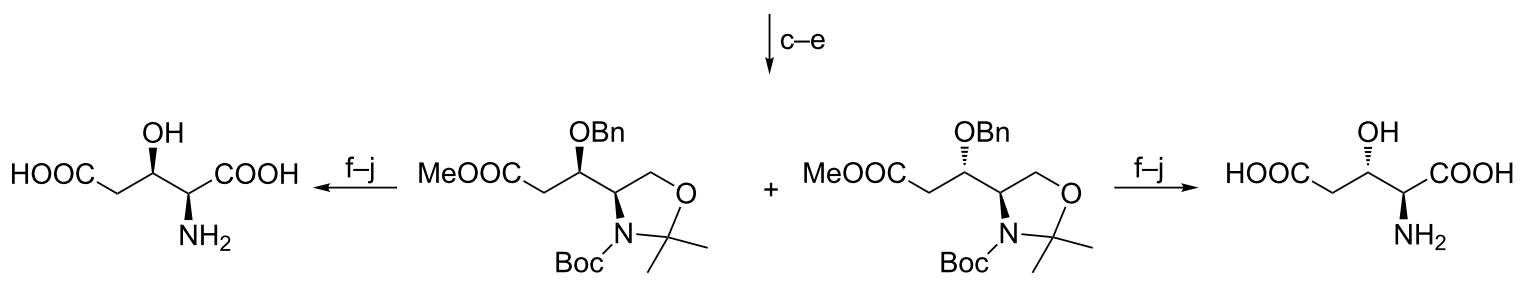

$(2 S, 3 R)-2$<smiles>N[C](CO)C(=O)O</smiles>

L-serine<smiles>CC12COC(C(N)C=O)(OC1)OC2</smiles>

10<smiles>C=CN[C@@H]([C@H](O)CCC(=O)OCCCC)C12OCC(C)(CO1)CO2</smiles>

$(2 S, 3 R)-11$<smiles>N[C](C(=O)O)[C@@H](O)CC(=O)O</smiles>

$(2 S, 3 R)-2$

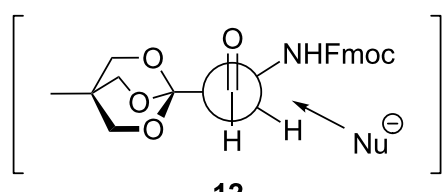

12

Scheme 3: Two-carbon homologation of the protected L-serine. Reagents and conditions: a) Fmoc-succinimide, $\mathrm{Na}_{2} \mathrm{CO}_{3}$, dioxane, $\mathrm{H}_{2} \mathrm{O}$; b) (3-hydroxymethyl)-3-methyloxetane, DCC, DMAP, $\mathrm{CH}_{2} \mathrm{Cl}_{2}$; c) $\mathrm{BF}_{3} \cdot \mathrm{OEt}_{2}, \mathrm{CH}_{2} \mathrm{Cl}_{2}$; d) oxalyl chloride, $\mathrm{DMSO}, \mathrm{DIPEA}, \mathrm{CH}_{2} \mathrm{Cl}_{2}$; e) $\mathrm{BrCH}_{2} \mathrm{COOt}-\mathrm{Bu}_{2} \mathrm{Zn}$, THF, reflux; f) TMSI; g) cation exchange column, $\mathrm{NH}_{4} \mathrm{OH}$; h) cation exchange column, $\mathrm{HCl}$.

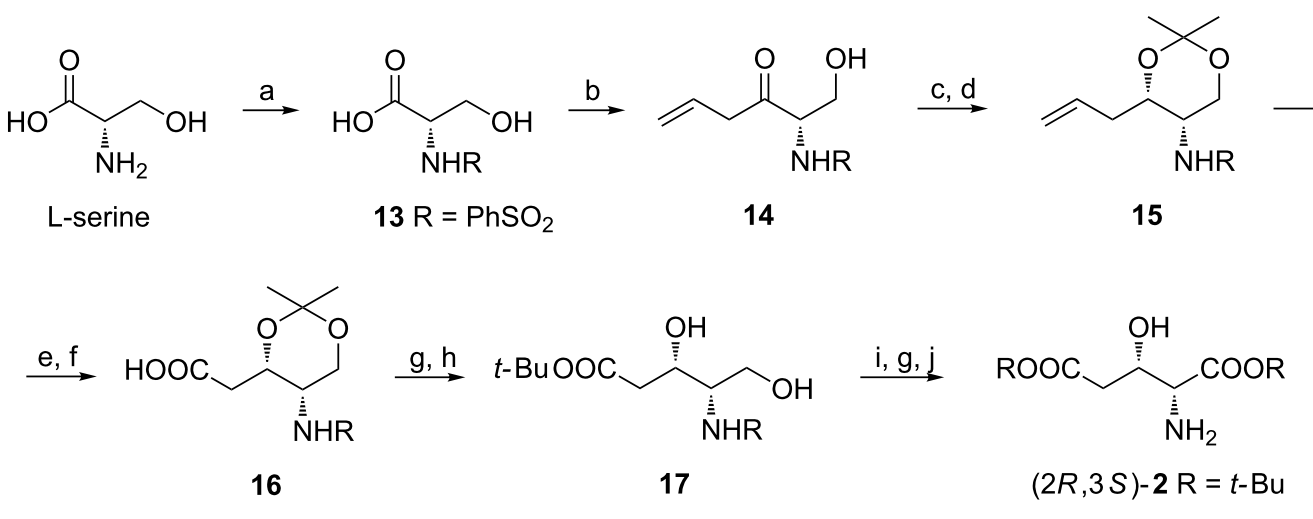

Scheme 4: Synthesis of di-tert-butyl ester of (2R,3S)-2 from L-serine. Reagents and conditions: a) $\mathrm{PhSO}_{2} \mathrm{Cl}_{1} \mathrm{~K}_{2} \mathrm{CO}_{3}, \mathrm{H}_{2} \mathrm{O}$; b) BuLi, THF; then $\mathrm{H}_{2} \mathrm{C}=\mathrm{CHCH}_{2} \mathrm{MgBr}$; c) L-selectride, THF; d) $\mathrm{Me}_{2} \mathrm{C}(\mathrm{OMe})_{2}$, PTSA, THF; e) $\mathrm{O}_{3}, \mathrm{CH}_{2} \mathrm{Cl}_{2}$, ether, then $\mathrm{Ph}_{3} \mathrm{P} ;$ f f $\mathrm{KMnO}_{4}$, acetone, $\mathrm{H}_{2} \mathrm{O}$; g) $t-\mathrm{BuOH}, N, N^{\prime}-$ diisopropyl-O-tert-butylisourea, $\mathrm{CH}_{2} \mathrm{Cl}_{2}$; h) $\mathrm{MeOH}, \mathrm{HCl}$ (gas); i) $\mathrm{O}_{2}$, $\mathrm{Pt}$, AcOEt, $\mathrm{H}_{2} \mathrm{O}$; j) electrochemical reduction. 
employing a Wittig reaction to give $Z$-alkene 19. To introduce the next center of chirality of the required configuration a iodocyclocarbamation reaction was applied to give trans-oxazolidin-2-one $(4 S, 5 S)$-20 after reduction of the carbon-iodine bond formed in the primary products of cyclization (via iodonium ion 22). Hydrogenolytic debenzylation preceded oxidation of the hydroxymethyl group to afford diester $(4 R, 5 S)-\mathbf{2 1}$ which after hydrolysis gave $(2 R, 3 S)-2$ as the hydrochloride (Scheme 5) [53]. Starting from $O$-benzyl-D-serine $(2 S, 3 R)-\mathbf{2}$ was obtained in a similar way.

Configurationally stable D-serinal derivative $(R)$-23 (prepared from D-serine [54]) which primarily exists as hemiacetal was subjected to cis-olefination with Stille's reagent at $-30{ }^{\circ} \mathrm{C}$ to produce $(S)-24$ in good yield. However, when the reaction mixture was warmed to $0{ }^{\circ} \mathrm{C}$ before quenching, an intramolecular cyclization occurred under basic conditions to give the oxazolidine $(4 S, 5 R)-25$ as an almost (>20:1) pure diastereoisomer. The hydroxy group which acted as a nucleophile preferred to attack the $r e$-face of the double bond for steric reasons. Selective removal of the silyl protective group allowed for the hydroxymethyl to carboxyl transformation to $(4 S, 5 R)-\mathbf{2 6}$, and hydrolysis afforded $(2 S, 3 R)-\mathbf{2}$ as the hydrochloride (Scheme 6) [55].

\section{From homochiral aziridine}

An interesting approach to protected $(2 S, 3 R)-2$ makes use of the aziridine $\left(2 R, 1^{\prime} S\right)-\mathbf{2 7}$ as a synthetic equivalent of L-serine (Scheme 7) [56]. Stereoselective reduction of ketone $\left(2 R, 1^{\prime} S\right)$ -<smiles>C[C+](=O)NC(C=O)COC(=O)O</smiles>

(S)-18<smiles>COC(=O)[C@H](COCc1ccccc1)NC(=O)OCc1ccccc1</smiles>

19
$(4 S, 5 S)-20$

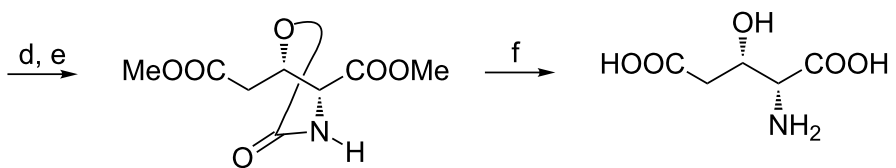

$(4 R, 5 S)-21$

$(2 R, 3 S)-2$

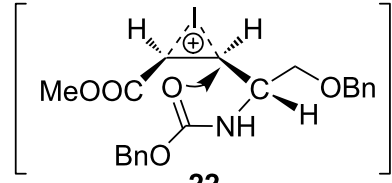

22

Scheme 5: Synthesis of $(2 R, 3 S)-2$ from O-benzyl-L-serine. Reagents and conditions: a) $\left(\mathrm{CF}_{3} \mathrm{CH}_{2} \mathrm{O}\right)_{2} \mathrm{P}(\mathrm{O}) \mathrm{CH} \mathrm{H}_{2} \mathrm{COOMe}, \mathrm{KHMDS}, 18-\mathrm{crown}-6$; b) $\mathrm{I}_{2}, \mathrm{MeCN}$; c) $\mathrm{Bu}_{3} \mathrm{SnH}$, AIBN, benzene, reflux; d) $\mathrm{H}_{2}, 10 \% \mathrm{Pd} / \mathrm{C}$, ethanol; e) $\mathrm{CrO}_{3}$, acetone, then $\mathrm{CH}_{2} \mathrm{~N}_{2}$, ether; f) $3 \mathrm{M} \mathrm{HCl}, 80{ }^{\circ} \mathrm{C}$.

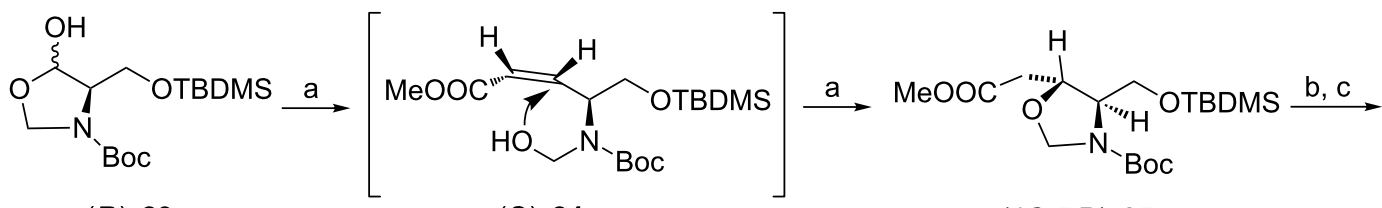

$(R)-23$

(S)- 24

$(4 S, 5 R)-25$<smiles>COC(=O)C[C@H]1OCN(C(=O)OCc2ccccc2)[C@H]1C(=O)O</smiles>

$(4 S, 5 R)-26$

$(2 S, 3 R)-2$ 


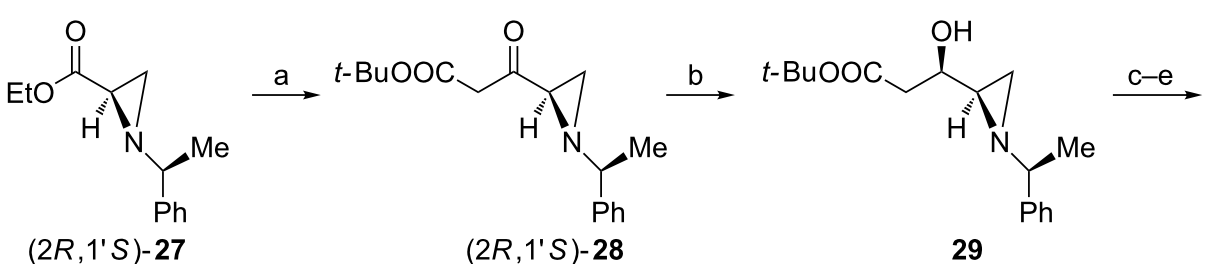

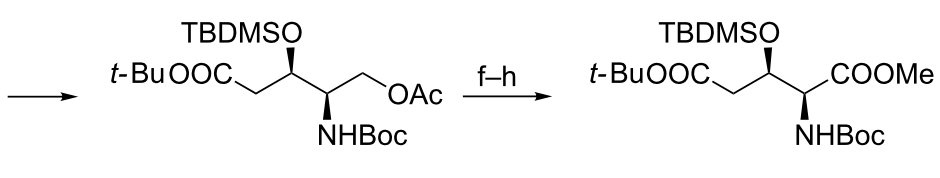

Scheme 7: Synthesis of the orthogonally protected (2S,3R)-2 from a chiral aziridine. Reagents and conditions: a) LiHMDS, AcOt-Bu, THF; b) $\mathrm{NaBH}_{4}$, iPrOH; c) $t$ - $\mathrm{BuMe}_{2} \mathrm{SiCl}$, TEA, DMAP, $\mathrm{CH}_{2} \mathrm{Cl}_{2}$; d) $\mathrm{AcOH}, \mathrm{CH}_{2} \mathrm{Cl}_{2}$; e) $\mathrm{H}_{2}, 10 \% \mathrm{Pd}(\mathrm{OH})_{2}, \mathrm{Boc}_{2} \mathrm{O}, \mathrm{MeOH}$; f) $\mathrm{KOH}, \mathrm{EtOH}$; g) $\mathrm{NaIO}$, $\mathrm{RuCl}$, $\left.\mathrm{CCl}_{4} / \mathrm{MeCN} / \mathrm{H}_{2} \mathrm{O} ; \mathrm{h}\right) \mathrm{Mel}, \mathrm{KHCO}_{3}$, DMF.

$\mathbf{2 8}$ gave hydroxyaziridine $\mathbf{2 9}$ as the major (10:1) product which, after the protection of the hydroxy group, was subjected to the regioselective aziridine ring opening, catalytic removal of the chiral auxiliary with simultaneous formation of a $\mathrm{N}$-Boc derivative 30. The hydroxymethyl to carboxylate transformation to form the protected diester $(2 S, 3 R)-\mathbf{3 1}$ required prior basic deacetylation followed by standard oxidation and esterification. Diastereoisomer $(2 S, 3 S)$-31 was also prepared employing the same methodology.

\section{From N-Boc-D-phenylglycinal}

Since the phenyl group has been applied for many occasions as a precursor of the carboxylic function selection of D-phenylglycine as a starting material in the synthesis of the $N$-Boc-protected $(2 S, 3 R)-2$ makes a useful addition to the existing methodologies (Scheme 8) [57]. Thus, $N$-Boc-D-phenylglycinal $(R)$-32 was in situ treated with benzylmagnesium chloride to give $N$-Boc-aminoalcohol $(1 R, 2 R)$-33 as a major $(9: 1)$ product easily separable chromatographically. Before oxidative degradation of both phenyl groups $(1 R, 2 R)-\mathbf{3 3}$ was protected as an acetonide. Intermediary diacid was first esterified with diazomethane, then the isopropylidene acetal was hydrolyzed, and diester saponification gave $N$-Boc-protected compound $(2 S, 3 R)-\mathbf{3 5}$.

\section{Via ketopinic acid functionalized $2(3 H)$-oxazolones}

When oxazolone 36 derived from $(R)-(-)$-ketopinic acid was reacted with bromine and trimethyl orthoacetate the enantiomerically pure bromomethoxy derivative $(4 R, 5 R)-37$ was prepared after crystallization of the reaction mixture. The precursor of the carboxymethyl group was first introduced with full retention of configuration employing a stannate chemistry to give $(4 R, 5 R)$ 38 after removal of a chiral auxiliary with lithium dibutylcuprate. Next, titanium tetrachloride-catalyzed cyanation secured another carboxy group and after a few transformations an oxazolidinone $(4 S, 5 R)$-39 was obtained as a major $(7: 1)$ product readily purified chromatographically. To complete the synthesis of $(2 S, 3 R)-2 N$-Boc protection preceded the cleavage of the oxazolidine ring while silylation of the hydroxy group was necessary before oxidation of the $\mathrm{C}=\mathrm{C}$ bond (Scheme 9) [58].

Further applications of the ketopinic acid framework as a chiral auxiliary relied on fine tuning of the steric environment around the carbonyl group. Thus, when compound $\mathbf{4 0}$ prepared using readily available $(S)-(+)$-ketopinic acid was reacted with phenylselenyl chloride in methanol the adduct 41 was formed with high diastereoselectivity (de 96\%) and was later separated

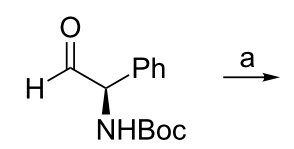

$(R)-32$<smiles>O=C(C=Cc1ccccc1)[NH2+][C@H](c1ccccc1)[C@H](O)Cc1ccccc1</smiles>

$(1 R, 2 R)-33$<smiles>[R]OC(=O)CC(O)C(NC(=O)O[R])C(=O)O</smiles>

$\mathrm{f} \longrightarrow \begin{aligned}(2 S, 3 R)-34 \mathrm{R} & =\mathrm{Me} \\ (2 S, 3 R)-35 \mathrm{R} & =\mathrm{H}\end{aligned}$ 
<smiles>CC1(C)C2CCC1(C(=O)n1ccoc1=O)C(=O)O2</smiles>

36<smiles>COC1C2(C)CCC1(C(=O)N1C(=O)O[C@@H](Br)[C@@H]1OC)C2(C)C</smiles>

$(4 R, 5 R)-37$<smiles>[R]C1NC(=O)O[C@@H]1CC=C</smiles><smiles>NC(CC(=O)O)C(O)C(=O)O</smiles>

$(2 S, 3 R)-2$

Scheme 9: Synthesis of (2S,3R)-2 employing ketopinic acid as chiral auxiliary. Reagents and conditions: a) $\mathrm{Br}_{2}, \mathrm{MeC}_{(} \mathrm{OMe}_{3}, \mathrm{Me}_{3} \mathrm{SiOTf}, \mathrm{CH}_{2} \mathrm{Cl}{ }_{2}$; b) $\mathrm{H}_{2} \mathrm{C}=\mathrm{CHCH}_{2} \mathrm{SnBu}_{3}, h v$; c) $\mathrm{Bu}_{2} \mathrm{CuLi}$; d) $\mathrm{Me}_{3} \mathrm{SiCN}, \mathrm{TiCl}_{4}, \mathrm{CH}_{2} \mathrm{Cl}_{2}$, then $\mathrm{MeOH}, \mathrm{HCl}$; e) $\left.\mathrm{Boc}_{2} \mathrm{O}, \mathrm{NaH}, \mathrm{THF} ; \mathrm{f}\right) \mathrm{Cs}_{2} \mathrm{CO}_{3}, \mathrm{MeOH}$ g) $t-\mathrm{BuMe} \mathrm{SiCl}_{2}$ imidazole, DMF; h) $\mathrm{NaIO}_{4}, \mathrm{KMnO}_{4}$, then $\mathrm{CH}_{2} \mathrm{~N}_{2}$, ether; i) TBAF; j) $6 \mathrm{M} \mathrm{HCl}$

chromatographically. Further transformations into dimethyl ester of $(2 S, 3 R)$-2 involved attachment of allyl and vinyl groups to form $(4 R, 5 R)-\mathbf{4 2}$ which was next oxidized to diacid and finally esterified to give dimethyl ester of $(2 S, 3 R)-2$ as the hydrochloride (Scheme 10) [59].

\section{By formation of the pyrrolidine ring}

Important synthetic strategies towards 3-hydroxyglutamic acids take advantage of the intermediary formation of the pyrrolidine ring. Addition of the dianion of $\mathbf{4 3}$ to acrolein gave a 69:31 mixture of diastereoisomers with compound 44 predominating which was easily separated on silica gel. When imine 45 was treated with iodine a stereoselective iodolactamization occurred to produce lactam 46 having the same configurations as found in $(2 S, 3 R)-\mathbf{2}$. To complete the synthesis of $(2 S, 3 R)-\mathbf{3 4}$ first the iodomethyl group was transformed in two steps into the hydroxymethyl moiety, both hydroxy groups were silylated, the chiral auxiliary was removed and the amide nitrogen was protected as $N$-Boc to furnish $(4 R, 5 R)-47$. Under basic conditions the pyrrolidin-2-one ring was cleaved to provide a five-carbon chain of the target molecule. The final steps included esterification, desilylation and selective oxidation of the hydroxymethyl group followed by esterification (Scheme 11) [60].<smiles>[R]C1C2CC(C)(C(=O)n3ccoc3=O)C1C(=O)O2</smiles>

$40 \mathrm{R}=\mathrm{CH}_{2} \mathrm{CH}_{2} \mathrm{OMe}$

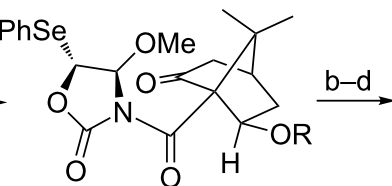

41<smiles>C=CC[C@H]1OC(=O)N[C@@H]1C=C</smiles>

$(4 R, 5 R)-42$<smiles>[R]O[R]O[Na]</smiles>

$(2 S, 3 R)-2 \mathrm{R}=\mathrm{Me}$

Scheme 10: Synthesis of dimethyl ester of $(2 S, 3 R)$-2 employing (1S)-2-exo-methoxyethoxyapocamphane-1-carboxylic acid as a chiral auxiliary. Reagents and conditions: a) $\mathrm{PhSeCl}, \mathrm{MeOH}$; b) $\mathrm{H}_{2} \mathrm{C}=\mathrm{CHCH}_{2} \mathrm{SnBu}_{3}$, ether, $h v$; c) BnSLi, THF; d) $\left(\mathrm{H}_{2} \mathrm{C}=\mathrm{CH}_{2} \mathrm{CuCNMgBr}_{3} \mathrm{BF}_{3}\right.$. OEt 2 , THF; e) $\mathrm{Boc}{ }_{2} \mathrm{O}$, DMAP, THF; f) $\left.\mathrm{Cs}_{2} \mathrm{CO}_{3}, \mathrm{MeOH} ; \mathrm{g}\right) \mathrm{Me}_{2} \mathrm{C}(\mathrm{OMe})_{2}, \mathrm{PTSA}$, benzene; h) $\mathrm{NalO}_{4}, \mathrm{KMnO}_{4}$, water/acetone; i) $\mathrm{CH}_{2} \mathrm{~N}_{2}$, ether; j) $\mathrm{MeOH}, \mathrm{HCl}(\mathrm{gas})$.

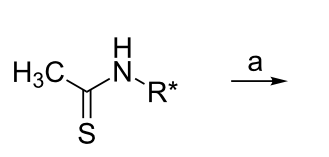

$$
\begin{aligned}
& 43 R^{*}=(S)-1 \text {-phenylethyl }
\end{aligned}
$$


Sharpless epoxidation of the allylic alcohol 48 gave a 46:11:33 mixture of $(S)-\mathbf{4 8},(3 R, 4 S)-\mathbf{4 9}$ and $(2 R, 3 R)-\mathbf{5 0}$. While $(S)-48$ is a product of kinetic resolution, the formation of $(2 R, 3 R)-50$ results from the intramolecular opening of the oxirane ring in $(3 R, 4 S)$-49. After chromatographic separation the hydroxy groups in $(2 R, 3 R)-\mathbf{5 0}$ were protected as silyl ethers to allow oxidation at $\mathrm{C} 5$ to produce pyrrolidine-2-one $(4 R, 5 R)$ 47 (Scheme 12) which was later transformed into $(2 S, 3 R)-\mathbf{3 4}$ as already shown (Scheme 11) [61].

\section{From L-malic acid}

(S)-Acetoxypyrrolidin-2,5-dione (51), readily available from L-malic acid [62], was carefully reduced and immediately acetylated to $(S)$-52 which was reacted with furan to produce a 67:33 mixture of readily separable $(2 S, 3 S)-\mathbf{5 3}$ and $(2 R, 3 S)-\mathbf{5 3}$, respectively. Steric hindrance of the acetoxy substituent controls the formation of higher amounts of the trans-isomer.
Ozone efficiently completed the degradation of the furan ring to the carboxyl group which was esterified with diazomethane to give methyl $(2 S, 3 S)$-3-acetoxypyroglutamate $(2 S, 3 S)$-54, a cyclized variant of 3-hydroxyglutamic acid. Treatment with a concentrated acid afforded $(2 S, 3 S)-2$ as the hydrochloride (Scheme 13) [63].

The other strategy which also commences from L-malic acid [64] showed much better carbon atom economy since the acetate $(S)$-55 was reacted with cyanide while to the acetate $(S)-52$ three unused carbon atoms were added. The cyanides $(4 S, 5 S)-56$ and $(4 S, 5 R)-56$ formed as a 57:43 mixture in a boron trifluoride-catalyzed reaction with trimethylsilyl cyanide were separated chromatographically. Their transformation into $(2 R, 3 S)-\mathbf{2}$ and $(2 S, 3 S)-\mathbf{2}$, respectively, required the removal of the $p$-methoxybenzyl group and an acidic hydrolysis (Scheme 14) [65].

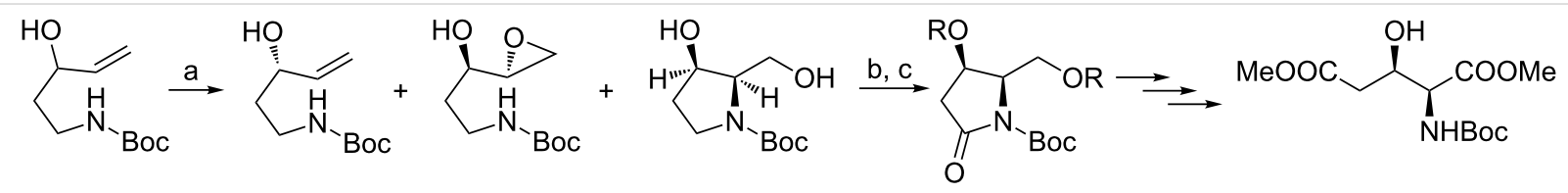

48

(S)-48

$(3 R, 4 S)-49$

$(2 R, 3 R)-50$

$(4 R, 5 R)-47 \mathrm{R}=\mathrm{TBDMS}$

$(2 S, 3 R)-34$

Scheme 12: Synthesis of N-Boc-protected dimethyl ester of (2S,3R)-2 via Sharpless epoxidation. Reagents and conditions: a) TBHP, D-(-)-DIPT, $\mathrm{Ti}(\mathrm{OiPr})_{4}, \mathrm{MS}, \mathrm{CH}_{2} \mathrm{Cl}_{2}$; b) $t$-BuMe $\mathrm{SiCl}_{2}$, imidazole, DMAP, DMF; c) $\mathrm{NalO}_{4}, \mathrm{RuO}_{2}, \mathrm{AcOEt} / \mathrm{H}_{2} \mathrm{O}$.<smiles>[CH]O[C@@H]1CC(=O)NC1=O</smiles>

$(S)-51$<smiles>CC(=O)OC1NC(=O)CC1[14CH3]</smiles>

$(S)-52$<smiles>CC(C)O[C@H]1CC(=O)N[C@H]1c1ccco1</smiles>

$(2 S, 3 S)-53$<smiles>COC(=O)C1NC(=O)C[C@H]1OC1CCCCC1</smiles>

(2S,3S)-54<smiles>NC(C(=O)O)C(O)CC(=O)O</smiles>

$(2 S, 3 S)-2$

Scheme 13: Synthesis of (2S,3S)-2 from the imide 51. Reagents and conditions: a) $\mathrm{NaBH}_{4}, \mathrm{MeOH} / \mathrm{CH}_{2} \mathrm{Cl}_{2}$; b) $\mathrm{Ac} 2 \mathrm{O}$, pyridinium perchlorate; c) furan, $\mathrm{ZnCl}_{2}, \mathrm{Me}_{3} \mathrm{SiCl}, \mathrm{MeNO}_{2}$; d) $\mathrm{O}_{3}, \mathrm{MeOH}$; e) $\mathrm{CH}_{2} \mathrm{~N}_{2}$, ether; f) $6 \mathrm{M} \mathrm{HCl}$.

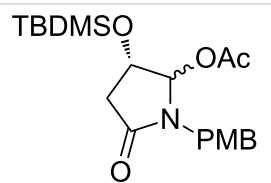

$(S)-55$

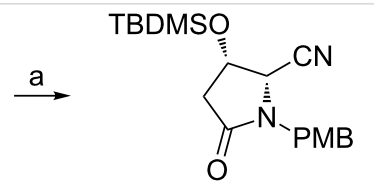

(4S,5S)-56

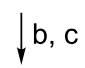<smiles>N[C@@H](C(=O)O)[C@@H](O)CC(=O)O</smiles>

$(2 R, 3 S)-2$<smiles>CCCCO[C@H]1CC(=O)N([PH](C)(=O)=O)[C@@H]1C#N</smiles>

(4S,5R)- 56<smiles>N[C@@H](CC(=O)O)[C@@H](O)C(=O)O</smiles>

$(2 S, 3 S)-2$ 


\section{From D-glucose}

D-Glucose may be used as a chiral template for the synthesis of (2S,3R)-2 since configurations at $\mathrm{C} 3$ and $\mathrm{C} 4$ in the hexose are retained in the target compound. The disclosed strategy relied on prior transformation of D-glucose into azidofuranoside $\mathbf{5 7}$ [66] and next to acid 58. Homologation of acid $\mathbf{5 8}$ was accomplished by the Arndt-Eistert reaction to give the methyl ester 59 from which benzyl ester $\mathbf{6 0}$ was obtained for easy hydrogenolytic removal in the last step. Hydrolysis of the isopropylidene acetal was followed by periodate cleavage of the $\mathrm{C} 1-\mathrm{C} 2$ bond in the furanose, oxidation of the already formed aldehyde to the acid and basic hydrolysis of the formate to afford the acid $(2 S, 3 R)$-61. Its allylation provided the ester (2S,3R)-62, a protected precursor of 3-hydroxyglutamate, from which $(2 S, 3 R)-2$ can be prepared by catalytic hydrogenolysis (Scheme 15) [67].

\section{4-Hydroxyglutamic acids}

All enantiomers of 4-hydroxyglutamic acid (3, Figure 4) were synthesized and characterized $[68,69]$ and absolute configurations were established $[68,69]$.

Although the majority of their preparations rely on enzymatic processes [5,68,70-73] several syntheses of non-racemic 4-hydroxyglutamic acids have been elaborated.

\section{By electrophilic hydroxylation at C4}

When the lithium enolate of dimethyl $\mathrm{N}$-Cbz-L-glutamate 63 was treated with Davis oxaziridine, an inseparable 9:1 mixture of diastereoisomers was formed with $(2 S, 4 S)$-64 predominating (Scheme 16) [74]. For sodium and potassium enolates diastereoselectivity of the hydroxylation was much lower (2.6:1 and 1:1, respectively). Acid hydrolysis of 64 gave $(4 S)$-4-hydroxy-L-glutamic acid $[(2 S, 4 S)-3]$ as the hydrochloride, however, its enantiomeric purity was not checked.

In connection with the total synthesis of thiopeptide antibiotic nosiheptide an orthogonally protected $(4 S)$-4-hydroxy-Lglutamic acid derivative 66 (Scheme 16) was required and it was obtained as a single diastereoisomer from $\mathbf{6 5}$ in the same way $[75,76]$.

\section{By bromination of L-glutamic acid}

Bromination of $N$-phthaloyl-L-glutamic acid [ $(S)$-67] followed by methanolysis gave a 2:1 mixture of threo and erythro diastereoisomers $(2 S, 4 S)-\mathbf{6 8}$ and $(2 S, 4 R)-68$, respectively (Scheme 17) [77,78]. A mixture of $(2 S, 4 S)-3$ and $(2 S, 4 R)-3$ obtained after hydrolysis was separated taking advantage of two phenomena: the preferential lactonization of $(2 S, 4 S)-3$ to produce 69 and much better solubility of $(2 S, 4 R)-3$ in water

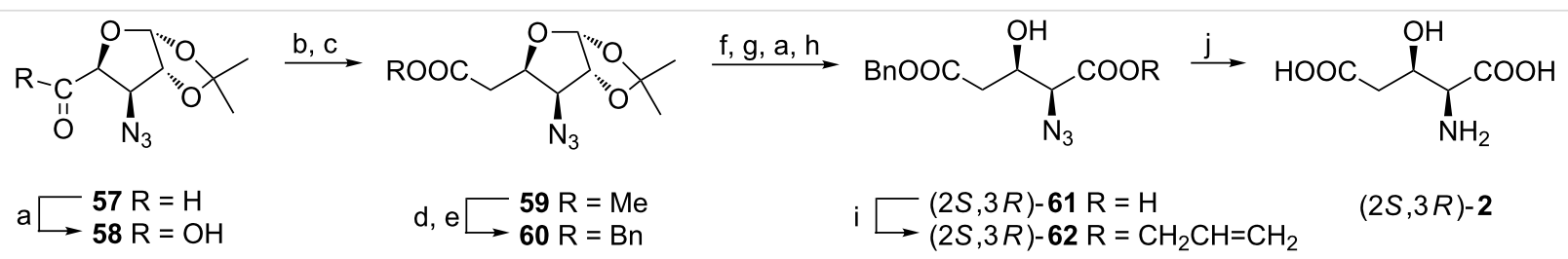

Scheme 15: Synthesis of (2S,3R)-2 from D-glucose. Reagents and conditions: a) $\mathrm{NaClO}_{2}, 30 \% \mathrm{H}_{2} \mathrm{O}_{2}, \mathrm{NaH}_{2} \mathrm{PO}_{4}, \mathrm{MeCN}$; b) ClCOOEt, NEt 3 , then $\mathrm{CH}_{2} \mathrm{~N}_{2}$, ether; c) $\mathrm{MeOH}, \mathrm{PhCOOAg}, \mathrm{NEt}_{3}$; d) $\mathrm{LiOH}$, THF/H $\mathrm{H}_{2} \mathrm{O}$; e) ClCOOBn, NEt 3 , DMAP; f) TFA, $\left.\mathrm{H}_{2} \mathrm{O} ; \mathrm{g}\right) \mathrm{NalO}_{4}$, acetone/water; h) $\mathrm{NaHCO}_{3}$, THF/ $\mathrm{H}_{2} \mathrm{O}$; i) $\mathrm{H}_{2} \mathrm{C}=\mathrm{CHCH}_{2} \mathrm{Br}, \mathrm{NaHCO}_{3}, \mathrm{DMF} ;$ j) $\mathrm{H}_{2}, 10 \% \mathrm{Pd} / \mathrm{C}, \mathrm{MeOH} / \mathrm{HCl}$.<smiles>NC(CC(O)C(=O)O)CC(O)C(=O)O</smiles>

$(2 S, 4 S)-3$
$(2 R, 4 R)-3$<smiles>N[C@@H](CC(O)C(=O)O)C(=O)O</smiles>

$(2 S, 4 R)-3$<smiles>N[C@@H](CC(O)C(=O)O)C(=O)O</smiles>

$(2 R, 4 S)-3$

Figure 4: Enantiomers of 3-hydroxyglutamic acid (3).

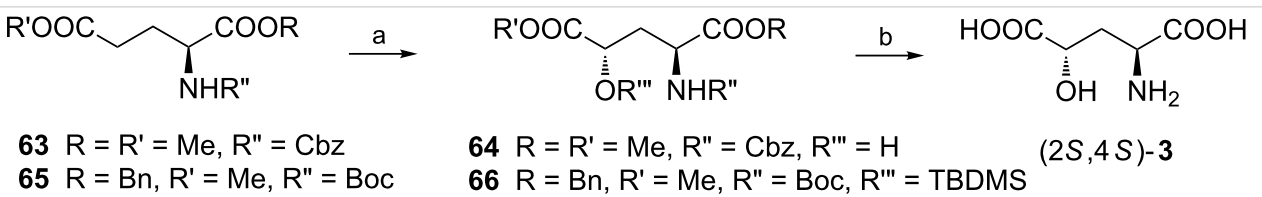




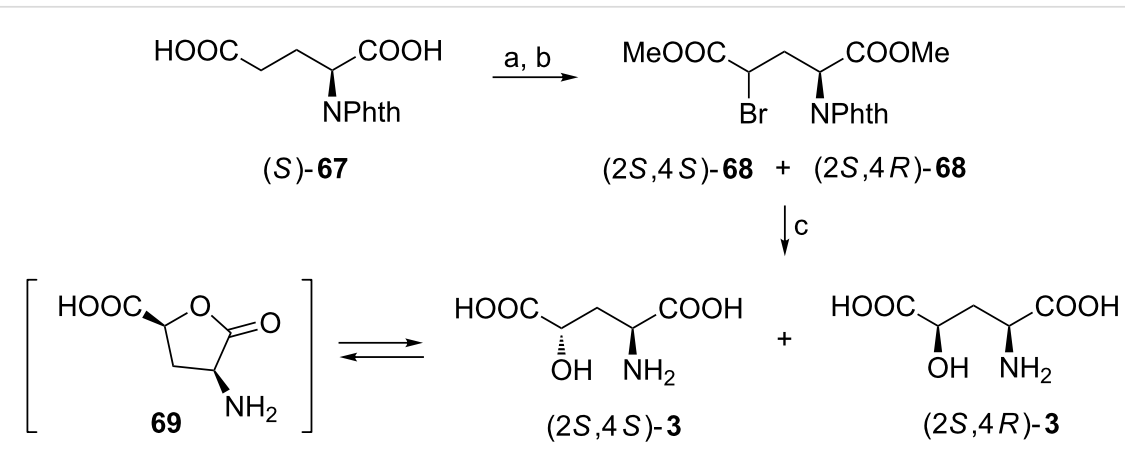

Scheme 17: Synthesis of all stereoisomers of 4-hydroxyglutamic acid (3). Reagents and conditions: a) $\mathrm{Br}_{2}, \mathrm{PBr}_{5}, h \mathrm{v}$; b) $\mathrm{MeOH}, \mathrm{reflux}$; c) $6 \mathrm{M} \mathrm{HCl}$, then pyridine, ethanol/water.

when compared with $\mathbf{6 9}$ and $(2 S, 4 S)-3$ [78]. Two other stereoisomers were synthesized in a similar way from $(R)-67$.

\section{By a nitrone-acrylate cycloaddition}

The isoxazolidine ring can be considered as another cyclic precursor to 4-hydroxyglutamic acids due to the easy cleavage of the $\mathrm{N}-\mathrm{O}$ bond and high trans diastereoselectivities of 1,3dipolar cycloadditions which allow to control stereochemistries at $\mathrm{C} 3$ and $\mathrm{C} 5[79,80]$. To illustrate this concept the $E / Z$ mixture of nitrone $\mathbf{7 0}$ was reacted with acrylamide $\mathbf{7 1}$ prepared from (2S)-bornane-10,2-sultam to afford mainly (20:1) the isoxazolidine (3S,5S)-72 easily separable from minor cycloadducts. The trans stereochemistry of the isoxazolidine ring in $\mathbf{7 2}$ was the consequence of the endo and exo additions to the $Z$ - and $E$-nitrones, respectively [80]. Further steps to the orthogonally protected $(2 S, 4 S)-73$ required selective hydrolysis of the chiral auxiliary, installation of the tert-butyl ester function and finally hydrogenolytic opening of the isoxazolidine ring with simultaneous protection of the amino group (Scheme 18).

\section{By Diels-Alder reaction}

Acylnitroso derivative $\mathbf{7 4}$ prepared from methyl $\mathrm{N}$-Boc-L-alaninate underwent Diels-Alder reaction with cyclopentadiene to produce equimolar amounts of easily separable cycloadducts $\mathbf{7 5}$ and 76 (Scheme 19) [81]. The bicyclic framework in the latter compound was first reduced and the hydroxy group was protected as acetate. Then the oxidative cleavage of the $\mathrm{C}=\mathrm{C}$ bond gave diacid 77 (readily purified as dimethyl ester 78) which is a dipeptide containing O-protected $(2 S, 4 R)$-4-hydroxyglutamic acid 3 (Scheme 19). The cycloadduct 75 can be transformed in a similar manner into non-proteinogenic D-amino acids.

\section{From 4-hydroxyproline}

4-Hydroxyproline could be used as a starting material in the chemical synthesis of 4-hydroxyglutamic acids when intermediary 4-hydroxypyroglutamic acids would have become available. This can be readily accomplished with ruthenium(IV) oxide. Application of this reagent to the acetate of methyl $N$-Boc-4hydroxyprolinate $[(2 S, 4 R)-79]$ gave the protected pyroglutamate 80 which was transformed into dimethyl $N$-Boc-4-hydroxyglutamate $[(2 S, 4 R)-81]$ (Scheme 20) [82]. To synthesize $(2 S, 4 S)-81$ the inversion of configuration at $\mathrm{C} 4$ executed by Mitsunobu reaction preceded oxidation at $\mathrm{C} 5$ and the ring opening [82]. $O$-Benzyl ethers of $(2 S, 4 R)-3$ and $(2 S, 4 S)-3$ were prepared by the same methodology [50].

Another approach to the orthogonally protected $(2 S, 4 S)-4-$ hydroxyglutamic acid $\mathbf{8 5}$ as an intermediate in the total synthe-<smiles></smiles>

71<smiles>[R]C(=O)[C@H]1C[C@@H](C(=O)OCC)CN1[R]</smiles>

$(3 S, 5 S)-72$<smiles>CCCCCCCC</smiles><smiles>[R6]N[C@@H](C[C@@H](O)C(=O)OCC)C(=O)OCC</smiles>

$(2 S, 4 S)-73$

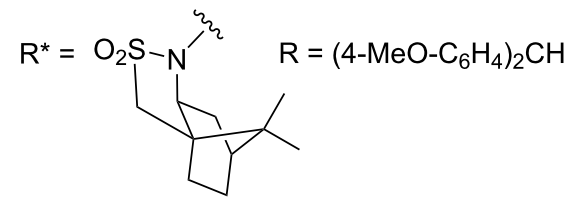




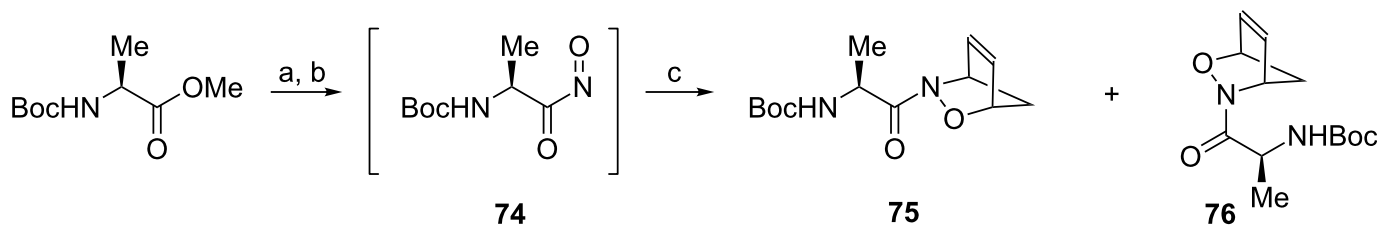

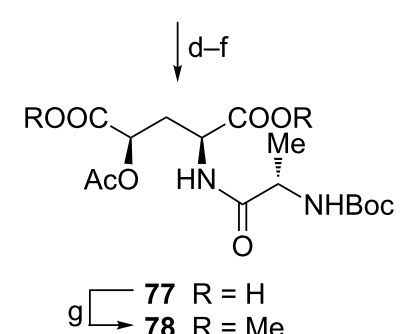

Scheme 19: Synthesis of (2S,4R)-4-acetyloxyglutamic acid as a component of a dipeptide. Reagents and conditions: a) $\mathrm{NH}_{2} \mathrm{OH}, \mathrm{MeOH}$; b) $\mathrm{Bu}_{4} \mathrm{NIO}_{4}$, $\mathrm{MeOH}$; c) cyclopentadiene, $\mathrm{MeOH}$; d) $\mathrm{Mo}(\mathrm{CO})_{6}, \mathrm{MeCN} / \mathrm{H}_{2} \mathrm{O}$; e) $\mathrm{Ac}_{2} \mathrm{O}$, pyridine/ $\mathrm{CH}_{2} \mathrm{Cl}_{2}$; f) $\mathrm{NaIO}_{4}, \mathrm{RuCl}_{3}, \mathrm{CCl}_{4} / \mathrm{MeCN} / \mathrm{H}_{2} \mathrm{O}$; g) $\mathrm{CH}_{2} \mathrm{~N}_{2}$, ether.

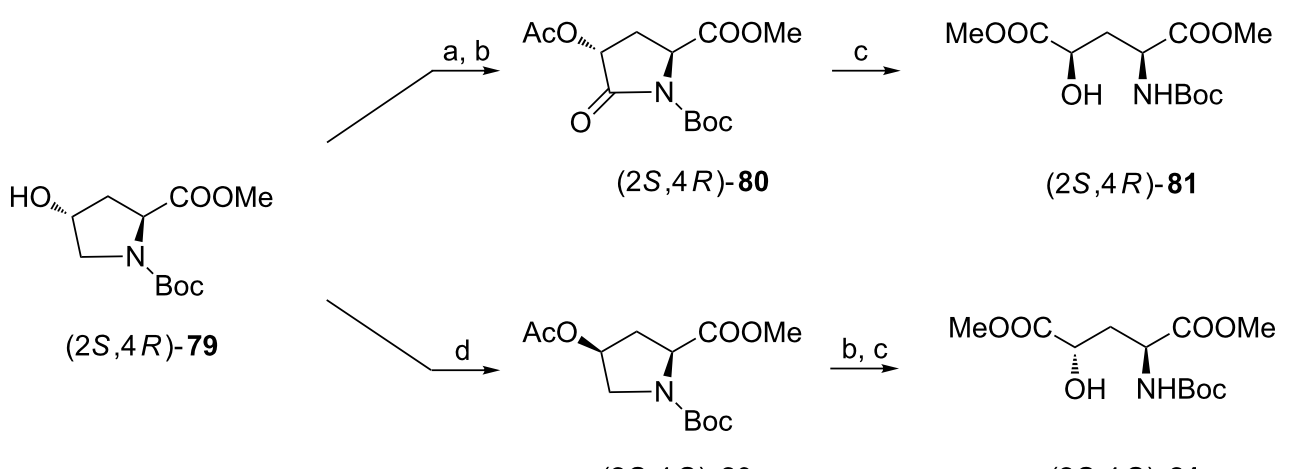

$(2 S, 4 S)-80$

$(2 S, 4 S)-81$

Scheme 20: Synthesis of $N$-Boc-protected dimethyl esters of $(2 S, 4 R)$ - and $(2 S, 4 S)-3$ from $(2 S, 4 R)-4$-hydroxyproline. Reagents and conditions: a) $\mathrm{Ac}_{2} \mathrm{O}$, pyridine; b) $\mathrm{RuO}_{2}, \mathrm{NalO}_{4}, \mathrm{AcOEt} / \mathrm{H}_{2} \mathrm{O}$; c) $\mathrm{MeOH}, \mathrm{K}_{2} \mathrm{CO}_{3}$; d) $\mathrm{AcOH}, \mathrm{Ph}_{3} \mathrm{P}, \mathrm{DEAD}$, THF.

sis of antibiotic nosiheptide [83,84] employs the $N$-Boc derivative of natural $(2 S, 4 R)$-4-hydroxyproline 82 as a starting material (Scheme 21) $[84,85]$. The inversion of configuration at $\mathrm{C} 4$ was carried out by intramolecular lactonization to form 83 by implementation of the Mitsunobu reaction. After opening of the lactone ring with trichloroethanol and silylation of the hydroxy group oxidation at $\mathrm{C} 5$ was performed in the usual way to give a pyroglutamate 84. Benzyl or $p$-methoxybenzyl esters 85a or $\mathbf{8 5 b}$ were next obtained after cleavage of $\mathbf{8 4}$ under basic conditions.

\section{From pyroglutamic acid}

In case of low availability of selected stereoisomers of 4-hydroxyprolines asymmetric syntheses of enantiomeric 4-hydroxypyroglutamates have been elaborated employing 1,3dipolar cycloadditions of homochiral nitrones and acrylates [86-<smiles>O=C(O)C1CC(O)CN1C(=O)O</smiles>

$(2 S, 4 R)-82$

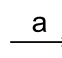<smiles>O=C(O)OCCCC1CN2CC1OC2=O</smiles>

83<smiles>[R6]N1C(=O)[C@@H](OC(C)(C)C)C[C@@H]1C(=O)[O-]</smiles>

84<smiles>[R]OC(=O)C[C@H](NC(=O)OCc1ccccc1)C(=O)O[Na]</smiles>

$85 a R^{\prime}=B n$

85b $R^{\prime}=P M B$

Scheme 21: Synthesis of orthogonally protected $(2 S, 4 S)-3$ from $(2 S, 4 R)-4$-hydroxyproline. Reagents and conditions: a) Ph ${ }_{3} P, D E A D, T H F$; b) $\mathrm{Cl}_{3} \mathrm{CCH}_{2} \mathrm{OH}(\mathrm{TceOH}), \mathrm{NaH}$, THF; c) $t$ - $\mathrm{BuMe}_{2} \mathrm{SiCl}$, imidazole, DMF; d) $\mathrm{RuO}_{2}, \mathrm{NalO}_{4}, \mathrm{CCl}_{4} / \mathrm{MeCN} / \mathrm{H}_{2} \mathrm{O}$; e) $\mathrm{BnOH}$ or $p-\mathrm{MeO}_{-} \mathrm{C}_{6} \mathrm{H}_{4}-\mathrm{CH} \mathrm{H}_{2} \mathrm{OH}, \mathrm{NaH}$, THF. 
88] or a Diels-Alder reaction using acylnitroso compounds [89]. However, when compared with these multistep approaches hydroxylation of pyroglutamic acid derivatives seems to be the simplest option. Treatment of the lithium enolate of benzyl $N$-Boc-pyroglutamate $(S)$-86 with Davis oxaziridine produced $(2 S, 4 R)-87$ (Scheme 22) [90-92]. HPLC investigation of the reaction mixture showed that $(2 S, 4 S)-87$ was not formed [90]. Stereospecific hydroxylation occurred on the opposite side to the benzyloxycarbonyl group, i.e., only re-face of the enolate was attacked for steric reasons. It is worth mentioning that hydroxylation of lithium enolates of pyroglutamate and glutamate results in the opposite stereochemical outcome at $\mathrm{C} 4$ $(R$ vs $S$ ) and formation of a single diastereoisomer for the cyclic system and a 9:1 mixture for the linear one.<smiles>CC(C)(C)OC(=O)N1C(=O)CCC1C(=O)OCc1ccccc1</smiles>

(S)-86

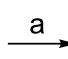<smiles>CC(C)(C)OC(=O)N1C(=O)[C@@H](O)CC1C(=O)OCc1ccccc1</smiles>

$(2 S, 4 R)-87$
Scheme 22: Synthesis of the protected (4R)-4-hydroxy-L-pyroglutamic acid $(2 S, 4 R)-87$ by electrophilic hydroxylation. Reagents and conditions: a) LiHMDS, THF, and then 3-phenyl- $N$-phenylsulfonyl oxaziridine.

\section{3,4-Dihydroxyglutamic acids}

Structures of enantiomers of 3,4-dihydroxy-L-glutamic acid (4) are depicted in Figure 5.

Several methodologies toward enantiomeric 3,4-dihydroxy-Lglutamic acid have been developed. In terms of carbon atom economy syntheses using 5-carbon synthons, e.g., pyroglutamic acid derivatives or pentoses, are the most valuable.

\section{From pyroglutamic acid}

Cleavage of the 5-membered ring in the protected epoxide $\mathbf{8 8}$ obtained from ( $S$ )-pyroglutamic acid [93-95] gave the methyl ester 89 which, when adsorbed on silica gel, smoothly underwent stereospecific epoxide ring opening to give the oxazolidinone 90 (Scheme 23) [96]. Before installation of the second carboxylic group the secondary hydroxy group in compound $\mathbf{9 0}$ was transformed to the silyl ether while the hydroxymethyl fragment was subjected first to hydrolysis of the acetal, then to oxidation and esterification of the acid to provide 91. After acidic hydrolysis $(2 S, 3 S, 4 R)$-3,4-dihydroxyglutamic acid $[(2 S, 3 S, 4 R)-4]$ was obtained as the hydrochloride.

To avoid racemization at $\mathrm{C} \alpha$ in sensitive amino acids the carboxy group was frequently masked as an orthoester. To illustrate this strategy dihydroxylation of the orthoester $\mathbf{9 2}$ (derived from L-pyroglutamic acid [97]) was performed to afford a single diastereoisomer $\mathbf{9 3}$ since the bulky orthoester residue allows the osmylation to occur from the opposite side (less hindered face). After purification of the diacetate 94 the recovery of acid $(2 S, 3 R, 4 R)-4$ was performed (Scheme 24) [98]. However, the hydrolysis was carried out under mild conditions to prevent decomposition of this stereoisomer including racemization at $\mathrm{C} \alpha$.

\section{From pentose via 2,3-aziridino-y-lactone}

In the so called " 2,3 -aziridino- $\gamma$-lactone methodology" $[18,99,100]$ ribose (or lyxose) is used as a starting material<smiles>NC(C(=O)O)C(O)C(O)C(=O)O</smiles>

$(2 S, 3 S, 4 S)-4$<smiles>NC(C(=O)O)C(O)C(O)C(=O)O</smiles>

$(2 S, 3 R, 4 S)-4$<smiles>NC(C(=O)O)C(O)C(O)C(=O)O</smiles>

$(2 S, 3 S, 4 R)-4$<smiles>N[C@@H](C(=O)O)[C@H](O)[C@H](O)C(=O)O</smiles>

$(2 S, 3 R, 4 R)-4$

Figure 5: Enantiomers of 3,4-dihydroxy-L-glutamic acid (4).

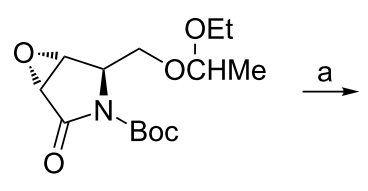

88

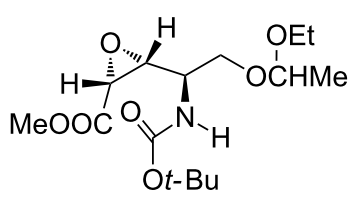

89

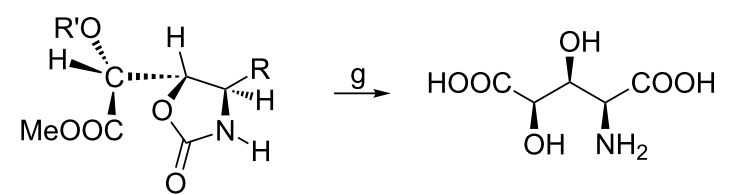

$(2 S, 3 S, 4 R)-4$ 


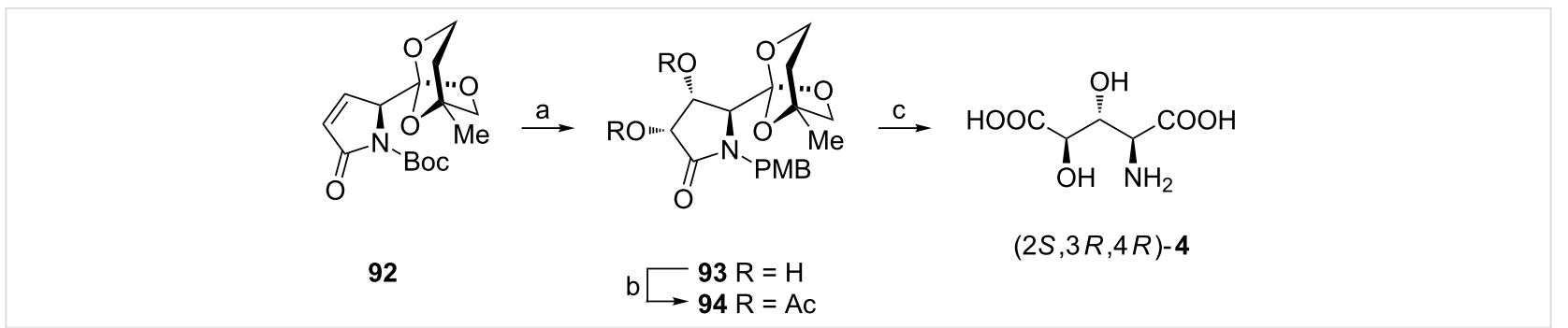

Scheme 24: Synthesis of $(2 S, 3 R, 4 R)-4$ from the orthoester 92. Reagents and conditions: a) $\mathrm{OsO}_{4}, \mathrm{NMO}$, acetone/water, $\mathrm{MeOH}$; b) $\mathrm{Ac}{ }_{2} \mathrm{O}$, pyridine; c) $1 \mathrm{M} \mathrm{HCl}$, reflux, then Dowex $50 \mathrm{~W}-\mathrm{X} 8$.

$[101,102]$ which is transformed into the lactone 95 in several steps [99]. Boron trifluoride etherate-catalyzed reaction of 95 with benzyl alcohol induces first opening of the 5-membered ring to form a benzyl ester and later the cleavage of the 3-membered ring to give a vicinal $N$-Cbz aminoalcohol with inversion of configuration. However, the reaction mixture (1:1) consists of the protected 3,4-dihydroxy-L-glutamic acid 96 and the respective $\gamma$-lactone $\mathbf{9 7}$ formed from $\mathbf{9 6}$ in the presence of acids. Benzyl alcohol was selected to refrain from decomposition of the final amino acids during the acid hydrolysis of, e.g., methyl esters [99] since for a mixture of 96 and 97 hydrogenolysis cleanly liberates $(2 S, 3 S, 4 S)-4$ (Scheme 25) [100].

This methodology opens the way to $(3 S, 4 S)$-3-hydroxy-4-methoxy- (104) and 3,4-dimethoxy-L-glutamic acid (105) since selective opening of the lactone ring in $\mathbf{9 5}$ can be accomplished by boron trifluoride etherate-catalyzed methanolysis at low temperatures to give dimethyl ester 98 (Scheme 25). Silver oxidepromoted methylation introduces a MeO-C4 unit. Regioselective aziridine ring opening in $\mathbf{9 9}$ was then carried out in the known way with benzyl alcohol or methanol to produce substituted dimethyl L-glutamates $\mathbf{1 0 0}$ and 101. To ensure clean deprotection in the final step transesterification of methyl to benzyl esters was successfully performed in the presence of titanium(IV) benzyloxide to afford dibenzyl esters 102 and 103, respectively. Their hydrogenolysis cleanly produced $(2 S, 3 S, 4 S)$ $\mathbf{1 0 4}$ and $(2 S, 3 S, 4 S)-\mathbf{1 0 5}[103]$.

\section{From tartaric acids}

Four-carbon chirons derived from D- or L-tartaric acids can be used as starting materials in syntheses of enantiomers of 3,4-dihydroxyglutamic acids since they contain a vicinal diol frag-

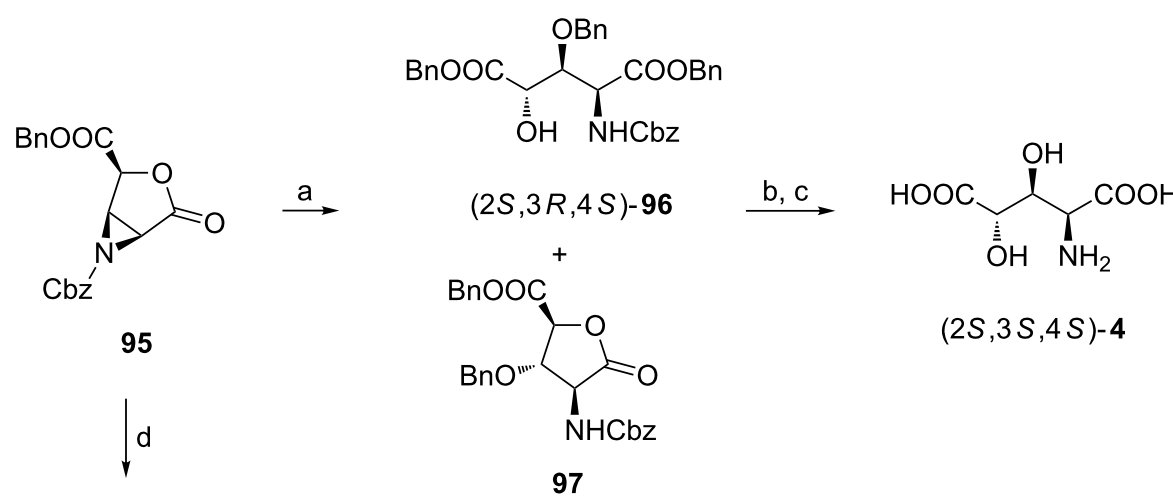<smiles>[R]OC(=O)[C@@H]1[C@H]([14CH3])[C@@H]1C(=O)OC</smiles>

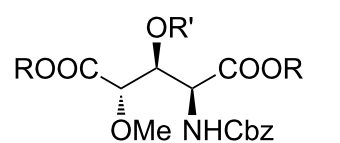<smiles>[R]OC(C(=O)O)C(N)C(=O)O</smiles><smiles>C=[R]1[13CH][13CH][13CH]1</smiles>

\footnotetext{
$\mathrm{g} \square 100 \mathrm{R}=\mathrm{Me}, \mathrm{R}^{\prime}=\mathrm{Bn}$

$\mathrm{g} \longrightarrow 102 \mathrm{R}=\mathrm{R}^{\prime}=\mathrm{Bn}$

$g \longrightarrow 101 R=M e, R^{\prime}=M e$
}

$04 \mathrm{R}=\mathrm{H}$

$105 \mathrm{R}=\mathrm{Me}$ 
ment of the known stereochemistry. To demonstrate this strategy cyclic imides 106a $(\mathrm{R}=$ TBDMS $)$ and $\mathbf{1 0 6} \mathbf{b}(\mathrm{R}=\mathrm{Ac})$ readily prepared from L-tartaric acid [104,105] were reduced and the respective hydroxylactams were acetylated to produce acetoxylactams 107a and $\mathbf{1 0 7} \mathbf{b}$, necessary intermediates in the next step (Scheme 26) $[106,107]$. The introduction of the cyano group was accomplished by boron trifluoride-catalyzed reaction with trimethylsilyl or tributyltin cyanides and the stereochemical outcome of these reactions strongly depends on the protecting group. Diastereoisomeric excesses of $60-80 \%$ were observed in the cyanation of tert-butyldimethylsilyl ether 107a and 108a was the major product, while for the acetate $107 \mathrm{~b}$ the selectivity was lower (de 54-64\%) with 109b predominating.
Nevertheless, efficient separation of the diastereoisomers was achieved for 108a and 109a only and they were deprotected to give enantiomerically pure $(2 S, 3 S, 4 R)-\mathbf{4}$ and $(2 R, 3 S, 4 R)-\mathbf{4}$, respectively. Application of D-tartaric acid as a starting material provided $(2 S, 3 R, 4 S)-\mathbf{4}$ and $(2 R, 3 R, 4 S)-\mathbf{4}$.

To secure the $(3 R, 4 R)$ and $(3 S, 4 S)$ configurations in 3,4 -hydroxyglutamic acids enantioselective reduction of the carbonyl group of the cyclic imide $\left(3 R^{*}, 4 S^{*}\right)$-110 prepared from mesotartaric acid [108] needs to be elaborated (Scheme 27) [109]. Low temperature reduction of this imide with a reagent obtained from $(R)$-binaphthol $[(R)$-BINAL-H] followed by acetylation furnished the triacetate $(3 R, 4 S)$-111 as a single diastereo-

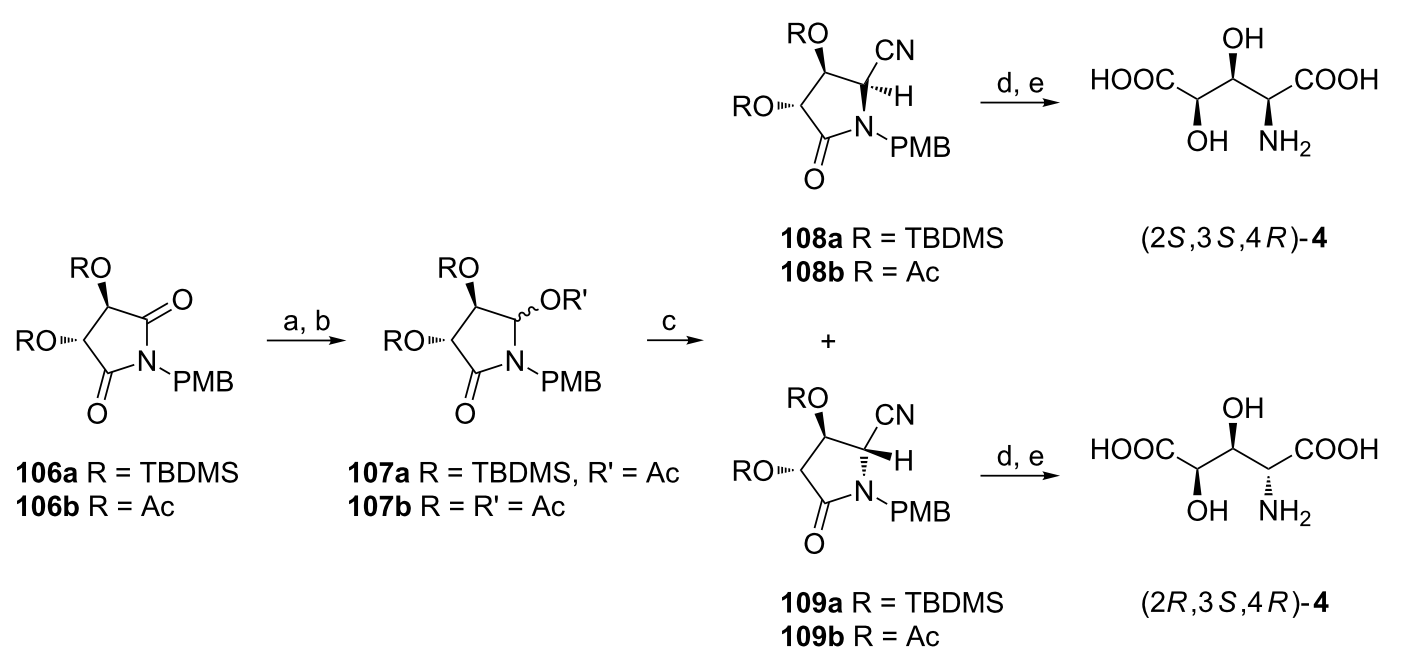

Scheme 26: Synthesis of $(2 S, 3 S, 4 R)-4$ and $(2 R, 3 S, 4 R)-4$ from cyclic imides 106. Reagents and conditions: a) $\mathrm{NaBH}_{4}, \mathrm{MeOH}$;) $\mathrm{Ac}_{2} \mathrm{O}, \mathrm{pyridine}$; c) $\mathrm{Me}_{3} \mathrm{SiCN}$ or $\mathrm{Bu}_{3} \mathrm{SnCN}, \mathrm{BF}_{3} \cdot \mathrm{OEt}_{2}$, toluene or $\left.\left.\mathrm{CH}_{2} \mathrm{Cl}_{2} ; \mathrm{d}\right) \mathrm{Ce}\left(\mathrm{NH}_{4}\right)_{2}\left(\mathrm{NO}_{3}\right)_{6}, \mathrm{MeCN} / \mathrm{H}_{2} \mathrm{O} ; \mathrm{e}\right) 6 \mathrm{M} \mathrm{HCl}$, reflux, then Dowex $50 \mathrm{~W}-\mathrm{X} 8$.

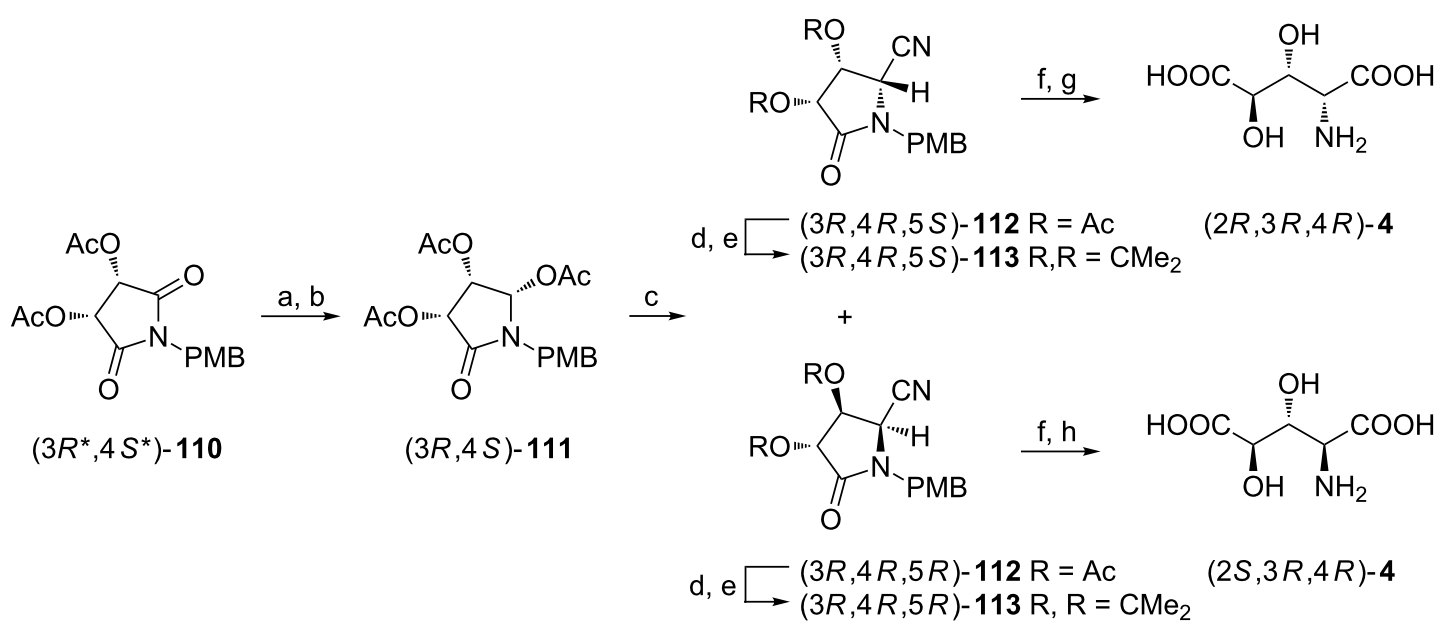

Scheme 27: Synthesis of $(2 R, 3 R, 4 R)-4$ and $(2 S, 3 R, 4 R)-4$ from the cyclic meso-imide 110. Reagents and conditions: a) (R)-BINAL-H (EtOH), THF; b) $\mathrm{Ac}_{2} \mathrm{O}$, pyridine; c) $\mathrm{Me}_{3} \mathrm{SiCN}, \mathrm{BF}_{3} \cdot \mathrm{OEt}_{2}$, toluene; d) $\mathrm{AcCl}$, $\mathrm{EtOH}$; e) $\mathrm{Me}_{2} \mathrm{C}(\mathrm{OMe})_{2}$, acetone, $\left.\left.\mathrm{PTSA} ; \mathrm{f}\right) \mathrm{Ce}\left(\mathrm{NH}_{4}\right)_{2}\left(\mathrm{NO}_{3}\right)_{6}, \mathrm{MeCN} / \mathrm{H}_{2} \mathrm{O} ; \mathrm{g}\right) 6 \mathrm{M} \mathrm{HCl}$, reflux, then Dowex 50W-X8; h) $1 \mathrm{M} \mathrm{HCl}$, reflux, then Dowex 50W-X8. 
isomer after chromatographic purification (Scheme 27). However, its cyanation as described earlier gave a 38:62 mixture of diacetates $(3 R, 4 R, 5 S)$-112 and $(3 R, 4 R, 5 R)$-112 which were separated as isopropylidene derivatives $(3 R, 4 R, 5 S)-\mathbf{1 1 3}$ and $(3 R, 4 R, 5 R)-113$. After deprotection they were converted into $(2 R, 3 R, 4 R)-\mathbf{4}$ and $(2 S, 3 R, 4 R)-\mathbf{4}$, respectively, although the final hydrolytic step in the synthesis of $(2 S, 3 R, 4 R)-4$ had to be carried out carefully since its instability to concentrated acid. Enantiomers $(2 S, 3 S, 4 S)-\mathbf{4}$ and $(2 R, 3 S, 4 S)-\mathbf{4}$ were obtained in a similar way using $(S)$-BINAL-H as a reducing agent, thus completing syntheses of all eight stereoisomers of 3,4-dihydroxyglutamic acid.

\section{From D-serine}

An interesting strategy to $(2 S, 3 S, 4 S)-\mathbf{4}$ (Scheme 28) [110] employs a protected serinal $(R)-\mathbf{2 3}$ [54]. Wittig olefination ex- tended the alkyl chain by two carbon atoms and simultaneously installed the $\mathrm{C}=\mathrm{C}$ bond which was subjected to the intramolecular epoxidation to give a $>20: 1$ mixture of aminoepoxides with the isomer $(2 S, 3 R, 4 R)-\mathbf{1 1 7}$ dominating. Without isolation this compound underwent another intramolecular cyclization in the 5-exo mode to form the oxazolidinone 118. To complete the synthesis of $(2 S, 3 S, 4 S)-4$ the secondary hydroxy group was protected as a pivalate, the hydroxymethyl fragment was oxidized after hydrolysis of the silyl ether and finally all protecting groups were removed by concentrated acid.

A very efficient synthesis of $(2 S, 3 S, 4 S)-\mathbf{4}$ starts from another serine-derived chiron, namely $O$-benzyl- $N$-Boc-D-serine [111], which was readily transformed to the $Z$-olefin 120 containing a benzophenone imine residue as a nitrogen protecting group (Scheme 29). Dihydroxylation of the $\mathrm{C}=\mathrm{C}$ bond gave a

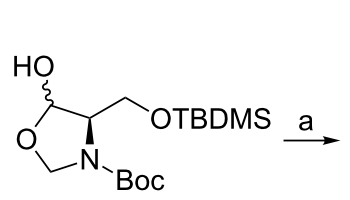

(R)-23<smiles>[R]CN(C(=O)OCc1ccccc1)/C(=C\C(=O)OC)C(=O)OC</smiles>

$\mathrm{b}-114 \mathrm{R}=\mathrm{OH}$

$\mathrm{b} \square 115 \mathrm{R}=\mathrm{OAC}$

$c \longrightarrow 116 \mathrm{R}=\mathrm{OOH}$

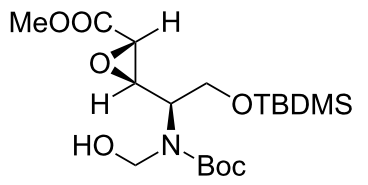

$(2 S, 3 R, 4 R)-117$<smiles>C#CCCC(C)(C)C</smiles>

$(2 S, 3 R, 4 R)-117$<smiles>COC(=O)[C@H](O)[C@@H]1OC(=O)N[C@H]1CO[Mg]</smiles>

118

$(2 S, 3 S, 4 S)-4$

Scheme 28: Synthesis of $(2 S, 3 S, 4 S)-4$ from the protected serinal $(R)-23$. Reagents and conditions: a) $\mathrm{Ph}_{3} \mathrm{P}=\mathrm{CHCOOMe}$, benzene; b) $\mathrm{Ac}_{2} \mathrm{O}, \mathrm{NEt}_{3}$, DMAP, $\mathrm{CH}_{2} \mathrm{Cl}_{2}$; c) $30 \% \mathrm{H}_{2} \mathrm{O}_{2}$, PTSA, $\mathrm{MgSO}_{4}$, DME; d) $\mathrm{K}_{2} \mathrm{CO}_{3}, \mathrm{MeOH}$; e) $\mathrm{MeOH}, 45^{\circ} \mathrm{C}$; f) $\mathrm{Piv}_{2} \mathrm{O}, \mathrm{NEt}_{3}, \mathrm{DMAP}, \mathrm{CH}_{2} \mathrm{Cl}_{2}$; g) PTSA, MeOH; h) $\mathrm{CrO}$, $\mathrm{H}_{5} \mathrm{O}_{6}, \mathrm{MeCN}$; i) $6 \mathrm{M} \mathrm{HCl}$, reflux.

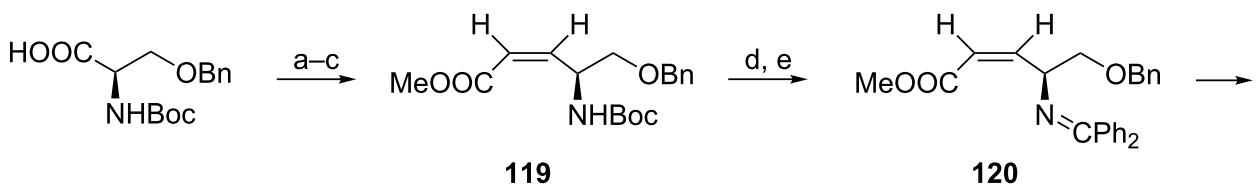

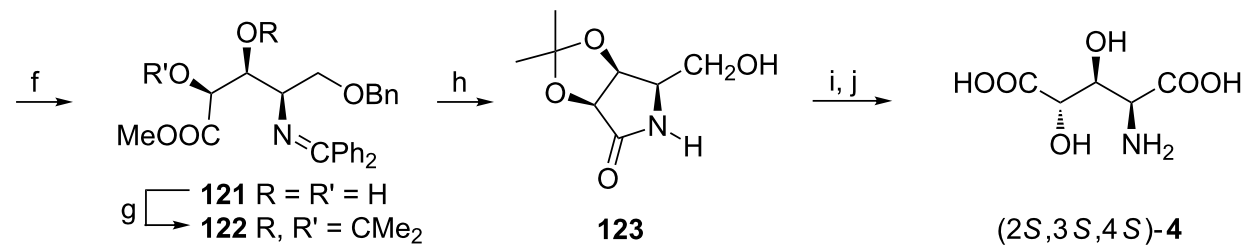

Scheme 29: Synthesis of (2S,3S,4S)-4 from O-benzyl-N-Boc-D-serine. Reagents and conditions: a) $\mathrm{CICOOiBu,} \mathrm{TEA,} \mathrm{DME}$ then $\mathrm{NaBH} 4$, MeOH; b) Dess-Martin periodinate, $\mathrm{CH}_{2} \mathrm{Cl}_{2}$; c) $\left(\mathrm{CF}_{3} \mathrm{CH}_{2} \mathrm{O}\right)_{2} \mathrm{P}(\mathrm{O}) \mathrm{CH}_{2} \mathrm{COOMe}, \mathrm{KHMDS}$, 18-crown, THF; d) $\mathrm{AcCl}, \mathrm{MeOH}$; e) $\mathrm{Ph} 2 \mathrm{C}=\mathrm{NH}_{2} \mathrm{CH}_{2} \mathrm{Cl}_{2}$; f) $\mathrm{OsO}$, $\mathrm{NMO}, \mathrm{THF} / \mathrm{H}_{2} \mathrm{O}$; g) $\mathrm{Me}_{2} \mathrm{C}(\mathrm{OMe})_{2}$, PPTS, benzene; h) $\mathrm{H}_{2}, 20 \% \mathrm{Pd}(\mathrm{OH})_{2}, \mathrm{MeOH}$; i) $\mathrm{RuCl}_{3}, \mathrm{NalO}_{4}, \mathrm{CCl}_{4} / \mathrm{MeCN} \mathrm{H}_{2} \mathrm{O}$; j) $6 \mathrm{M} \mathrm{HCl}, 80{ }^{\circ} \mathrm{C}$. 
10:1 mixture with $(2 S, 3 S, 4 R)-\mathbf{1 2 1}$ as a major product which was transformed into the isopropylidene derivative $(2 S, 3 S, 4 R)-\mathbf{1 2 2}$ to facilitate purification. Hydrogenolysis allowed to remove the $\mathrm{N}$ - and O-protecting groups and was followed by the spontaneous cyclization to a pyrrolidine-2-one $(3 S, 4 S, 5 R)-\mathbf{1 2 3}$ [111]. Oxidation of the hydroxymethyl group and acid hydrolysis gave $(2 S, 3 S, 4 S)-4$ [112].

\section{By enantioselective conjugate addition and asymmetric dihydroxylation}

An orthogonally protected 3,4-dihydroxy-L-glutamic acid was envisioned as an intermediate in the projected synthesis of (+)-polyoxamic acid (Scheme 30) [113]. To this end the anion generated from benzophenone imine of tert-butyl glycinate $\mathbf{1 2 4}$ acted as a Michael donor in the presence of homochiral catalyst to give a ca. 1:1 mixture of diastereoisomeric iminoselenides 125 with an ee up to $96 \%$ (Scheme 30). Next, a 9-phenylfluorenyl protecting group was installed to prevent racemization and oxidation allowed to introduce the $\mathrm{C}=\mathrm{C}$ bond leading to 3,4 didehydroglutamate $(S)$-126. Asymmetric dihydroxylation of (S)-126 (ee 96\%) gave $(2 S, 3 S, 4 R)-\mathbf{1 2 7}$ (de 94\%).

\section{Synthetic applications of enantiomeric hydroxy-L-glutamic acids}

Besides numerous applications of hydroxyglutamic acids in studies on glutamate receptors they have also been used as starting materials in syntheses of other compounds including complex natural products (Figure 6).

Thus, (2S,3R)-5-(benzyloxy)-2-[(tert-butoxycarbonyl)amino]-3hydroxy-5-oxopentanoic acid served as a precursor in the total synthesis of longicatenamycin A [25]. Syntheses of several modified cephems started from dimethyl $(2 S, 4 R)-N$-Boc-4hydroxyglutamate (81) [114]. Protected 4-hydroxyglutamic acids $(2 S, 4 S)-66[75,76]$ and $(2 S, 4 S)-85 \mathbf{a}[84,85]$ after installation of the thiazole ring at the $\mathrm{C} 1$ terminus were incorporated into the thiopeptide antibiotic nosiheptide. The total synthesis of biphenomycin B relied on installation of a five-membered chain derived from a protected tert-butyl $(2 S, 4 R)$-4-hydroxypyroglutamate [115]. While the protected methyl $(2 S, 4 S)$-4-hydroxypyroglutamate formed a basis for the construction of the alkaloid hemerocallisamine skeleton [37], its tert-butyl counterpart was used as a starting material in a multistep synthesis of a functionalized exo-methylenecyclopentane skeleton as an entecavir intermediate [116]. On the other hand, the stereospecific alkylation of methyl $(2 R, 4 R)$-4-hydroxypyroglutamate was employed in the important approach to $(2 R, 4 R)$-monatin [117]. Carbapenems can be generated from the intermediary enantiomeric 3-hydroxy- or 4 hydroxy-L-glutamic acids in cell-free environments [118]. Diazotization of $(2 R, 3 R)-2$ provided 2-deoxy-L-1,4-ribonolactone which was later transformed into 2'-deoxy-L-thymidine and other nucleosides [119]. Syntheses of all four enantiomers of tricholomic acid of interest as a flycidal compound as well as in receptor studies [120] were accomplished starting from enantiomeric 3-hydroxyglutamic acid, e.g., $(2 S, 3 R)$-3-hydroxyglutamic acid was converted in a few steps into $(2 S, 5$ 'S $)$-tricholomic acid [47]. The absolute configuration of $(R)-(-)$-carnitine was established by enzymatic decarboxylation of (2S,3R)-3-hydroxyglutamic acid followed by exhaustive methylation [121]. Fluoroglutamic acids are of special interest for PET imaging [122] and among other methods they are available from 3- or 4-hydroxyglutamic acids by direct hydroxy to fluoride displacement $[91,123,124]$. Deuterium- [72] and tritium-labelled [125] glutamic acids have also been prepared from 4-hydroxyglutamic acids via 4-mesyloxy derivatives. And finally reduction of the ethoxycarbonyl group in $(2 S, 3 S, 4 R)-\mathbf{1 2 7}$ followed by acidic hydrolysis gave $(+)$-polyoxamic acid [113].

\section{Conclusion}

The synthesis of nonracemic hydroxyglutamic acids is an active area of research and it was stimulated by studies on glutamate receptors to modulate the biological activity of L-glutamic acid from one side and applications as starting materials in total syntheses of complex natural products from the other. In general, the syntheses started from other amino acids and were designed to preserve the stereochemical integrity at $\mathrm{C} \alpha$ while inducing chirality at $\mathrm{C} \beta$ - or $\mathrm{C} \gamma-\mathrm{OH}$ centers. Thus, both enantiomers of serine or their synthetic equivalents, glutamic acid, 4-hydroxyproline and pyroglutamic acid were most frequently employed. Alternatively, $\alpha$-hydroxy acids (malic, tartaric) offered the opportunity to induce chirality at $\mathrm{C} \alpha-\mathrm{N}$ while the stereochemistry

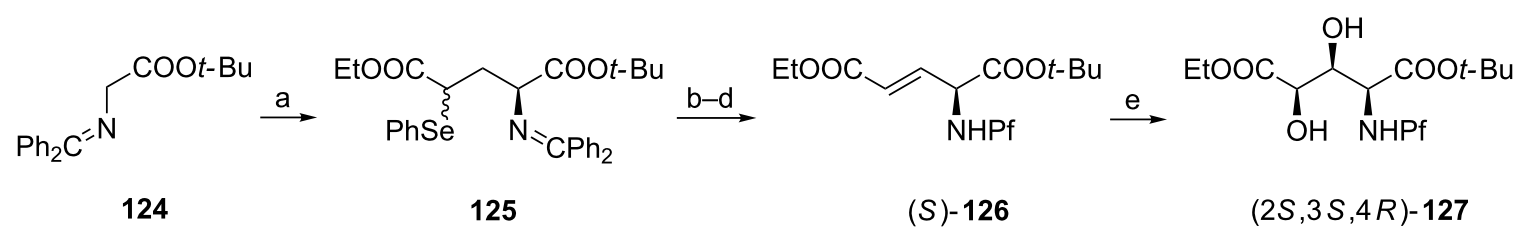

Scheme 30: Synthesis of $(2 S, 3 S, 4 R)-127$ by enantioselective conjugate addition and asymmetric dihydroxylation. Reagents and conditions: a) ethyl 1-phenylselenylacrylate, chiral PTC, $50 \% \mathrm{KOH}, \mathrm{CH}_{2} \mathrm{Cl}_{2}$; b) $1 \mathrm{M} \mathrm{HCl}$, THF; c) 9-bromo-9-phenylfluorene, $\mathrm{K}_{2} \mathrm{PO}_{4}, \mathrm{PbNO}_{2}, \mathrm{MeCN}$ d) $\mathrm{NaIO}_{4}$, $\left.\mathrm{NaHCO}_{3}, \mathrm{MeOH} / \mathrm{H}_{2} \mathrm{O} ; \mathrm{e}\right) \mathrm{K}_{2} \mathrm{Os}_{2}(\mathrm{OH})_{4}$, hydroquinine 4-chlorobenzoate $(\mathrm{HQN}-\mathrm{CLB}), \mathrm{K}_{2} \mathrm{CO}_{3}, \mathrm{~K} 3 \mathrm{Fe}(\mathrm{CN})_{6}, t-\mathrm{BuOH} / \mathrm{H}_{2} \mathrm{O}$. 


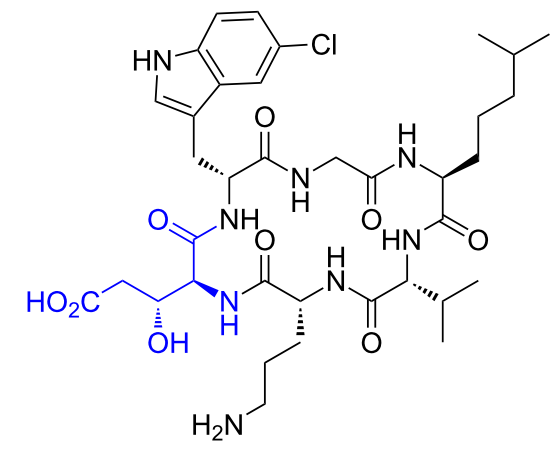

longicatenamycin A [25]

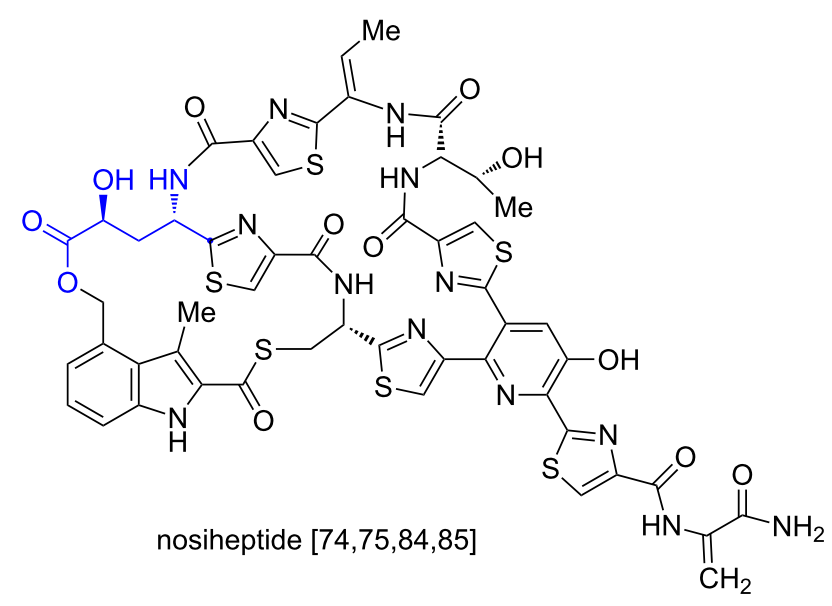<smiles>COCc1ccc(C=O)n1C(C[C@H](O)C(N)=O)C(C)=O</smiles>

(2S,4 S)-hemerocallisamine [37]<smiles>[3H]C1C[C@@H](O)[C@@H](CO)O1</smiles>

2'-deoxy-L-thymidine [119]<smiles></smiles>

entecavir [116]<smiles>N[C](C(=O)O)C1CC(O)=NO1</smiles>

(2S,5' S)-tricholomic acid [120]<smiles>N[C@@H](C[C@](O)(Cc1c[nH]c2ccccc12)C(=O)O)C(=O)O</smiles>

$(2 R, 4 R)$-monatin [117]<smiles>COC(=O)CC(O)CC=[N+](C)C</smiles>

$(R)-(-)$-carnitine [121]<smiles>O=C(O)C1=CC(O)C2CC(=O)N12</smiles>

carbapenem [118]<smiles>NC(C(=O)O)C(O)[C@H](O)CO</smiles>

(+)-polyoxamic acid [113]

Figure 6: Structures of selected compounds containing hydroxyglutamic motives (in blue).

at $\mathrm{C}-\mathrm{OH}$ was retained. Monosaccharides (glucose, ribose) also appeared attractive providing two or three predefined stereogenic centers. In more sophisticated approaches application of chiral auxiliaries allowed to generate vicinal or 1,3-aminoalcohol units of the required stereochemistries.

Currently available synthetic methodologies towards hydroxyglutamic acids significantly differ in terms of carbon atom economy and preparative simplicity although carbon-wasteless approaches do exist. For future use as starting materials in total syntheses of complex natural products synthetic methodology to orthogonally protected hydroxyglutamic acids were also discussed which allow, for example, to differentiate between $\alpha$ and $\omega$ carboxy groups.

Although syntheses of particular enantiomers of hydroxyglutamic acids look to be optimal, e.g., $(2 S, 4 S)-\mathbf{3}$ or $(2 S, 4 R)-\mathbf{3}$ via hydroxylation of the protected glutamic or pyroglutamic acids, 
synthetic methodologies to the other enantiomers may require improvements or even designing new ways especially when larger quantities are needed and we hope this review will stimulate further research in this area.

\section{Acknowledgements}

This work was supported by the Medical University of Lodz internal funds (503/3-014-01/503-31-001 and 502-03/3-014-01/ 502-34-079).

\section{References}

1. Rodwell, V. W. Metabolism of Purine \& Pyrimidine Nucleotides. In Harper's Biochemistry, 25th ed.; Murray, R. K.; Granner, D. K.; Mayes, P. A.; Rodwell, V. W., Eds.; The McGraw-Hill Companies, 2000; pp 386-401.

2. Livingston, R. B.; Venditti, J. M.; Cooney, D. A.; Carter, S. K. Adv. Pharmacol. Chemother. 1971, 8, 57-120. doi:10.1016/s1054-3589(08)60594-3

3. Corti, A.; Franzini, M.; Paolicchi, A.; Pompella, A. Anticancer Res. 2010, 30, 1169-1181.

4. Dutta, S.; Ray, S.; Nagarajan, K. Saudi Pharm. J. 2013, 21, 337-343. doi:10.1016/j.jsps.2012.12.007

5. Zhou, Y.; Danbolt, N. C. J. Neural Transm. 2014, 121, 799-817. doi:10.1007/s00702-014-1180-8

6. Meldrum, B. S. J. Nutr. 2000, 130, 1007S-1015S. doi:10.1093/jn/130.4.1007s

7. Moloney, M. G. Nat. Prod. Rep. 2002, 19, 597-616. doi:10.1039/b103777n

8. Lee, H. G.; Zhu, X.; O'Neill, M. J.; Webber, K.; Casadesus, G.; Marlatt, M.; Raina, A. K.; Perry, G.; Smith, M. A. Acta Neurobiol. Exp. 2004, 64, 89-98.

9. Fan, M. M. Y.; Raymond, L. A. Prog. Neurobiol. 2007, 81, 272-293. doi:10.1016/j.pneurobio.2006.11.003

10. Johnson, K.; Conn, P.; Niswender, C. CNS Neurol. Disord.: Drug Targets 2009, 8, 475-491. doi:10.2174/187152709789824606

11. Akins, P. T.; Atkinson, R. P. Curr. Med. Res. Opin. 2002, 18, s9-s13. doi:10.1185/030079902125000660

12. Sierra-Paredes, G.; Sierra-Marcuno, G. CNS Neurol. Disord.: Drug Targets 2007, 6, 288-300. doi:10.2174/187152707781387251

13. Kunishima, N.; Shimada, Y.; Tsuji, Y.; Sato, T.; Yamamoto, M.; Kumasaka, T.; Nakanishi, S.; Jingami, H.; Morikawa, K. Nature 2000, 407, 971-977. doi:10.1038/35039564

14. Armstrong, N.; Gouaux, E. Neuron 2000, 28, 165-181. doi:10.1016/s0896-6273(00)00094-5

15. Armstrong, N.; Sun, Y.; Chen, G.-Q.; Gouaux, E. Nature 1998, 395, 913-917. doi:10.1038/27692

16. Bessis, A.-S.; Bolte, J.; Pin, J.-P.; Acher, F. Bioorg. Med. Chem. Lett. 2001, 11, 1569-1572. doi:10.1016/s0960-894x(01)00158-5

17. Bunch, L.; Pickering, D. S.; Gefflaut, T.; Vinatier, V.; Helaine, V.; Amir, A.; Nielsen, B.; Jensen, A. A. ChemMedChem 2009, 4, 1925-1929. doi:10.1002/cmdc.200900258

18. Dauban, P.; de Saint-Fuscien, C.; Acher, F.; Prézeau, L.; Brabet, I.; Pin, J.-P.; Dodd, R. H. Bioorg. Med. Chem. Lett. 2000, 10, 129-133. doi:10.1016/s0960-894x(99)00641-1
19. Alaux, S.; Kusk, M.; Sagot, E.; Bolte, J.; Jensen, A. A.; Bräuner-Osborne, H.; Gefflaut, T.; Bunch, L. J. Med. Chem. 2005, 48, 7980-7992. doi:10.1021/jm050597z

20. Vandenberg, R. J.; Mitrovic, A. D.; Chebib, M.; Balcar, V. J.; Johnston, G. A. R. Mol. Pharmacol. 1997, 51, 809-815. doi:10.1124/mol.51.5.809

21. Takeuchi, H.; Yokoi, I.; Kurono, M. Neuropharmacology 1977, 16, 849-856. doi:10.1016/0028-3908(77)90147-2

22. Nakajima, T.; Nomoto, K.; Ohfune, Y.; Shiratori, Y.; Takemoto, T.; Takeuchi, H.; Watanabe, K. Br. J. Pharmacol. 1985, 86, 645-654. doi:10.1111/j.1476-5381.1985.tb08941.x

23. Zhang, W.; Liu, G. J.; Takeuchi, H.; Kurono, M. Gen. Pharmacol. 1996, 27, 487-497. doi:10.1016/0306-3623(95)02036-5

24. Shoji, J.; Sakazaki, R. J. Antibiot. 1970, 23, 418-419. doi:10.7164/antibiotics.23.418

25. von Nussbaum, F.; Anlauf, S.; Freiberg, C.; Benet-Buchholz, J.; Schamberger, J.; Henkel, T.; Schiffer, G.; Häbich, D. ChemMedChem 2008, 3, 619-626. doi:10.1002/cmdc.200700297

26. Broberg, A.; Menkis, A.; Vasiliauskas, R. J. Nat. Prod. 2006, 69, 97-102. doi:10.1021/np050378g

27. Strieker, M.; Nolan, E. M.; Walsh, C. T.; Marahiel, M. A. J. Am. Chem. Soc. 2009, 131, 13523-13530. doi:10.1021/ja9054417

28. Schleifer, K. H.; Plapp, R.; Kandler, O. Biochem. Biophys. Res. Commun. 1967, 28, 566-570. doi:10.1016/0006-291x(67)90351-8

29. Virtanen, A. I.; Hietala, P. K. Acta Chem. Scand. 1955, 9, 175-176. doi:10.3891/acta.chem.scand.09-0175

30. Bell, E. A.; Meier, L. K.; Sørensen, H. Phytochemistry 1981, 20, 2213-2216. doi:10.1016/0031-9422(81)80115-x

31. Hatanaka, S.-i. Acta Chem. Scand. 1962, 16, 513-514. doi:10.3891/acta.chem.scand.16-0513

32. Li, X.; Knight, J.; Todd Lowther, W.; Holmes, R. P. Biochim. Biophys. Acta, Mol. Basis Dis. 2015, 1852, 2700-2705. doi:10.1016/j.bbadis.2015.09.016

33. Adams, E.; Goldstone, A. J. Biol. Chem. 1960, 235, 3504-3512.

34. Grove, M. D.; Weisleder, D.; Daxenbichler, M. E. Tetrahedron 1973, 29, 2715-2719. doi:10.1016/s0040-4020(01)93391-5

35. Ogawa, Y.; Konishi, T. Chem. Pharm. Bull. 2009, 57, 1110-1112. doi:10.1248/cpb.57.1110

36. Ogawa, Y.; Kawai, M.; Kinoshita, A.; Konishi, T. Chem. Nat. Compd. 2014, 49, 991-995. doi:10.1007/s10600-014-0806-2

37. Wood, J. M.; Furkert, D. P.; Brimble, M. A. J. Nat. Prod. 2017, 80, 1926-1929. doi:10.1021/acs.jnatprod.7b00314

38. Zang, Y.; Cichewicz, R. H.; Nair, M. G. Life Sci. 2004, 75, 753-763. doi:10.1016/j.Ifs.2004.03.002

39. Lorenz, P.; Stermitz, F. R.; Ismail, L. D. Phytochemistry 1999, 52, 63-66. doi:10.1016/s0031-9422(99)00172-7

40. Plaza, A.; Viehrig, K.; Garcia, R.; Müller, R. Org. Lett. 2013, 15, 5882-5885. doi:10.1021/ol402967y

41. Ohyama, T.; Kurihara, Y.; Ono, Y.; Ishikawa, T.; Miyakoshi, S.; Hamano, K.; Arai, M.; Suzuki, T.; Igari, H.; Suzuki, Y.; Inukai, M. J. Antibiot. 2000, 53, 1108-1116. doi:10.7164/antibiotics.53.1108

42. Sugawara, T.; Tanaka, A.; Tanaka, K.; Nagai, K.; Suzuki, K.; Suzuki, T. J. Antibiot. 1998, 51, 435-438. doi:10.7164/antibiotics.51.435

43. Virtanen, A. I.; Ettala, T. Acta Chem. Scand. 1957, 11, 182-184. doi:10.3891/acta.chem.scand.11-0182

44. Müller, A. L.; Uusheimo, K. Acta Chem. Scand. 1965, 19, 1987-1988. doi:10.3891/acta.chem.scand.19-1987 
45. Kaneko, T.; Yoshida, R.; Katsura, H. Nippon Kagaku Zasshi 1959, 80, 316-321. doi:10.1246/nikkashi1948.80.3_316

46. Kaneko, T.; Yosida, R. Optical resolution of $\beta$-hydroxyglutamic acid. JP 36002174 B, 1961.

47. Kamiya, T. Chem. Pharm. Bull. 1969, 17, 890-894. doi:10.1248/cpb.17.890

48. Umio, S.; Kamiya, T.; Nishitsuji, K. Chem. Pharm. Bull. 1966, 14, 925-930. doi:10.1248/cpb.14.925

49. Garner, P. Tetrahedron Lett. 1984, 25, 5855-5858. doi:10.1016/s0040-4039(01)81703-2

50. Tamborini, L.; Conti, P.; Pinto, A.; Colleoni, S.; Gobbi, M.; De Micheli, C. Tetrahedron 2009, 65, 6083-6089. doi:10.1016/j.tet.2009.05.054

51. Blaskovich, M. A.; Lajoie, G. A. J. Am. Chem. Soc. 1993, 115, 5021-5030. doi:10.1021/ja00065a010

52. Roemmele, R. C.; Rapoport, H. J. Org. Chem. 1989, 54, 1866-1875. doi:10.1021/jo00269a023

53. Dell'Uomo, N.; Di Giovanni, M. C.; Misiti, D.; Zappia, G.; Delle Monache, G. Liebigs Ann. Chem. 1994, 641-644. doi:10.1002/jlac.199419940618

54. Yoo, D.; Oh, J. S.; Lee, D.-W.; Kim, Y. G. J. Org. Chem. 2003, 68, 2979-2982. doi:10.1021/jo026653a

55. Kim, H.; Yoo, D.; Kwon, S.; Kim, Y. G. Tetrahedron: Asymmetry 2009, 20, 2715-2719. doi:10.1016/j.tetasy.2009.11.023

56. Park, C. S.; Choi, H. G.; Lee, H.; Lee, W. K.; Ha, H.-J. Tetrahedron: Asymmetry 2000, 11, 3283-3292. doi:10.1016/s0957-4166(00)00311-6

57. Veeresa, G.; Datta, A. Tetrahedron Lett. 1998, 39, 3069-3070. doi:10.1016/s0040-4039(98)00360-8

58. Kunieda, T.; Ishizuka, T.; Higuchi, T.; Hirobe, M. J. Org. Chem. 1988, 53, 3381-3383. doi:10.1021/jo00249a055

59. Ishizuka, T.; Ishibuchi, S.; Kunieda, T. Tetrahedron 1993, 49, 1841-1852. doi:10.1016/s0040-4020(01)80540-8

60. Takahata, H.; Takamatsu, T.; Yamazaki, T. J. Org. Chem. 1989, 54, 4812-4822. doi:10.1021/jo00281a022

61. Takahata, H.; Banba, Y.; Tajima, M.; Momose, T. J. Org. Chem. 1991, 56, 240-245. doi:10.1021/jo00001a045

62. Chamberlin, A. R.; Chung, J. Y. L. J. Am. Chem. Soc. 1983, 105, 3653-3656. doi:10.1021/ja00349a051

63. Shiokawa, S.; Ohta, T.; Nozoe, S. Chem. Pharm. Bull. 1992, 40, 1398-1399. doi:10.1248/cpb.40.1398

64. Louwrier, S.; Ostendorf, M.; Boom, A.; Hiemstra, H.; Speckamp, W. N. Tetrahedron 1996, 52, 2603-2628. doi:10.1016/0040-4020(95)01085-8

65. Oba, M.; Mita, A.; Kondo, Y.; Nishiyama, K. Synth. Commun. 2005, 35, 2961-2966. doi:10.1080/00397910500278446

66. Tronchet, J. M. J.; Gentile, B.; Ojha-Poncet, J.; Moret, G.; Schwarzenbach, D.; Barbalat-Rey, F.; Tronchet, J. Carbohydr. Res. 1977, 59, 87-93. doi:10.1016/s0008-6215(00)83295-4

67. Kumar, K. S. A.; Chattopadhyay, S. RSC Adv. 2015, 5, 19455-19464. doi:10.1039/c5ra01340b

68. Benoiton, L.; Winitz, M.; Birnbaum, S. M.; Greenstein, J. P. J. Am. Chem. Soc. 1957, 79, 6192-6198. doi:10.1021/ja01580a023

69. Lee, Y. K.; Kaneko, T. Bull. Chem. Soc. Jpn. 1973, 46, 3494-3498. doi:10.1246/bcsj.46.3494

70. Adams, E.; Goldstone, A. Biochim. Biophys. Acta 1963, 77, 133-135. doi:10.1016/0006-3002(63)90475-x

71. Passerat, N.; Bolte, J. Tetrahedron Lett. 1987, 28, 1277-1280. doi:10.1016/s0040-4039(00)95345-0
72. Ducrocq, C.; Decottignies-Le Maréchal, P.; Azerad, R. J. Labelled Compd. Radiopharm. 1985, 22, 61-70. doi:10.1002/jlcr.2580220109

73. Guérard-Hélaine, C.; Heuson, E.; Ndiaye, M.; Gourbeyre, L.; Lemaire, M.; Hélaine, V.; Charmantray, F.; Petit, J.-L.; Salanoubat, M. de Berardinis, V.; Gefflaut, T. Chem. Commun. 2017, 53, 5465-5468. doi:10.1039/c7cc00742f and references cited therein.

74. Hanessian, S.; Vanasse, B. Can. J. Chem. 1993, 71, 1401-1406. doi:10.1139/v93-181

75. Belhadj, T.; Nowicki, A.; Moody, C. J. Synlett 2006, 3033-3036. doi:10.1055/s-2006-951502

76. Kimber, M. C.; Moody, C. J. Chem. Commun. 2008, 591-593. doi:10.1039/b715644h

77. Krasnov, V. P.; Alekseeva, L. V.; Firsova, N. A.; Kodess, I. K.; Burde, N. L. Pharm. Chem. J. 1984, 18, 369-372. doi:10.1007/bf00776786

78. Krasnov, V. P.; Bukrina, I. M.; Zhdanova, E. A.; Kodess, M. I.; Korolyova, M. A. Synthesis 1994, 961-964. doi:10.1055/s-1994-25614

79. Geffaut, T.; Bauer, U.; Airola, K.; Koskinen, A. M. P. Tetrahedron: Asymmetry 1996, 7, 3099-3102. doi:10.1016/0957-4166(96)00407-7

80. Hyean Kim, B.; Curran, D. P. Tetrahedron 1993, 49, 293-318. doi:10.1016/s0040-4020(01)80300-8

81. Ritter, A. R.; Miller, M. J. Tetrahedron Lett. 1994, 35, 9379-9382. doi:10.1016/s0040-4039(00)78547-9

82. Zhang, X.; Schmitt, A. C.; Jiang, W. Tetrahedron Lett. 2001, 42, 5335-5338. doi:10.1016/s0040-4039(01)01030-9

83. Wojtas, K. P.; Riedrich, M.; Lu, J.-Y.; Winter, P.; Winkler, T.; Walter, S.; Arndt, H.-D. Angew. Chem., Int. Ed. 2016, 55, 9772-9776. doi:10.1002/anie.201603140

84. Lu, J.-Y.; Riedrich, M.; Mikyna, M.; Arndt, H.-D. Angew. Chem., Int. Ed. 2009, 48, 8137-8140. doi:10.1002/anie.200903477

85. Lu, J.-Y.; Riedrich, M.; Wojtas, K.; Arndt, H.-D. Synthesis 2013, 45, 1300-1311. doi:10.1055/s-0032-1317810

86. Merino, P.; Anoro, S.; Franco, S.; Merchan, F. L.; Tejero, T.; Tuñon, V. J. Org. Chem. 2000, 65, 1590-1596. doi:10.1021/jo991560n

87. Merino, P.; Revuelta, J.; Tejero, T.; Chiacchio, U.; Rescifina, A.; Piperno, A.; Romeo, G. Tetrahedron: Asymmetry 2002, 13, 167-172. doi:10.1016/s0957-4166(02)00072-1

88. Merino, P.; Mates, J. A.; Revuelta, J.; Tejero, T.; Chiacchio, U.; Romeo, G.; lannazzo, D.; Romeo, R. Tetrahedron: Asymmetry 2002, 13, 173-190. doi:10.1016/s0957-4166(02)00088-5

89. Huang, W.; Miller, M. J. Tetrahedron: Asymmetry 2008, 19, 2835-2838. doi:10.1016/j.tetasy.2008.12.013

90. Ohta, T.; Hosoi, A.; Nozoe, S. Tetrahedron Lett. 1988, 29, 329-332. doi:10.1016/s0040-4039(00)80087-8

91. Avent, A. G.; Bowler, A. N.; Doyle, P. M.; Marchand, C. M.; Young, D. W. Tetrahedron Lett. 1992, 33, 1509-1512. doi:10.1016/s0040-4039(00)91661-7

92. Greck, C.; Thomassigny, C.; Le Bouc, G. ARKIVOC 2012, No. viii, 231-249. doi:10.3998/ark.5550190.0013.821

93. Thottathil, J. K.; Moniot, J. L.; Mueller, R. H.; Wong, M. K. Y.; Kissick, T. P. J. Org. Chem. 1986, 51, 3140-3143. doi:10.1021/jo00366a011

94. Herdeis, C.; Hubmann, H. P.; Lotter, H. Tetrahedron: Asymmetry 1994, 5, 119-128. doi:10.1016/s0957-4166(00)80492-9 
95. Langlois, N.; Moro, A. Eur. J. Org. Chem. 1999, 3483-3488. doi:10.1002/(sici)1099-0690(199912)1999:12<3483::aid-ejoc3483>3.0 .co;2-e

96. Langlois, N. Tetrahedron Lett. 1999, 40, 8801-8803. doi:10.1016/s0040-4039(99)01873-0

97. Oba, M.; Nishiyama, N.; Nishiyama, K. Tetrahedron 2005, 61, 8456-8464. doi:10.1016/j.tet.2005.06.051

98. Oba, M.; Nishiyama, N.; Nishiyama, K. Chem. Commun. 2003, 776-777. doi:10.1039/b300554b

99. Dauban, P.; Chiaroni, A.; Riche, C.; Dodd, R. H. J. Org. Chem. 1996, 61, 2488-2496. doi:10.1021/jo951983z

100.Dauban, P.; de Saint-Fuscien, C.; Dodd, R. H. Tetrahedron 1999, 55, 7589-7600. doi:10.1016/s0040-4020(99)00405-6

101.Dubois, L.; Dodd, R. H. Tetrahedron 1993, 49, 901-910. doi:10.1016/s0040-4020(01)80332-x

102.Dauban, P.; Dubois, L.; Tran Huu Dau, M. E.; Dodd, R. H. J. Org. Chem. 1995, 60, 2035-2043. doi:10.1021/jo00112a027

103.Yan, Z.; Weaving, R.; Dauban, P.; Dodd, R. H. Tetrahedron Lett. 2002, 43, 7593-7595. doi:10.1016/s0040-4039(02)01762-8

104. Yoda, H.; Shirakawa, K.; Takabe, K. Tetrahedron Lett. 1991, 32, 3401-3404. doi:10.1016/s0040-4039(00)92719-9

105. Klaver, W. J.; Speckamp, W. N. J. Am. Chem. Soc. 1989, 111, 2588-2595. doi:10.1021/ja00189a036

106. Oba, M.; Koguchi, S.; Nishiyama, K. Tetrahedron Lett. 2001, 42, 5901-5902. doi:10.1016/s0040-4039(01)01120-0

107. Oba, M.; Koguchi, S.; Nishiyama, K. Tetrahedron 2002, 58, 9359-9363. doi:10.1016/s0040-4020(02)01218-8

108. Ostendorf, M.; Romagnoli, R.; Pereiro, I. C.; Roos, E. C.; Moolenaar, M. J.; Speckamp, W. N.; Hiemstra, H. Tetrahedron: Asymmetry 1997, 8, 1773-1789. doi:10.1016/s0957-4166(97)00154-7

109. Oba, M.; Koguchi, S.; Nishiyama, K. Tetrahedron 2004, 60, 8089-8092. doi:10.1016/j.tet.2004.06.109

110.Kim, H.; Yoo, D.; Choi, S. Y.; Chung, Y. K.; Kim, Y. G. Tetrahedron: Asymmetry 2008, 19, 1965-1969. doi:10.1016/j.tetasy.2008.07.036

111.Jeon, J.; Lee, J. H.; Kim, J.-W.; Kim, Y. G. Tetrahedron: Asymmetry 2007, 18, 2448-2453. doi:10.1016/j.tetasy.2007.10.004

112. Jeon, J.; Shin, N.; Lee, J. H.; Kim, Y. G. Appl. Chem. Eng. (Kongop Hwahak) 2014, 25, 392-395. doi:10.14478/ace.2014.1045

113.Lee, Y.-J.; Park, Y.; Kim, M.-h.; Jew, S.-s.; Park, H.-g. J. Org. Chem. 2011, 76, 740-743. doi:10.1021/jo102272h

114. Yamawaki, K.; Sano, M.; Sato, J. Preparation of cephem derivative having catechol group. WO Patent WO 2013051597 A1 20130411 , 2013.

115.He, Y.-P.; Tan, H.; Arve, L.; Baumann, S.; Waldmann, H.; Arndt, H.-D. Chem. - Asian J. 2011, 6, 1546-1556. doi:10.1002/asia.201000908

116. Liu, N.; Mu, X.; Li, Q. Entecavir intermediates and preparation method thereof. WO Patent WO 2014108011 A1 20140717, 2014.

117.Amino, Y. Chem. Pharm. Bull. 2016, 64, 1242-1247. doi:10.1248/cpb.c16-00358

118.Blake, W. J.; Klein-Marcuschamer, D. Cell-free preparation of carbapenems. WO Patent WO 2013036787 A2 20130314, 2013.

119.Storer, R.; Moussa Adel, W.; Jing, Y.; Chaudhuri, N.; Mathieu, S.; Stewart, A. Synthesis of $\beta$-L-2-deoxy nucleosides. WO Patent WO 2005003374 A2 20050113, 2005.

120.Pinto, A.; Conti, P.; De Amici, M.; Tamborini, L.; Madsen, U.; Nielsen, B.; Christesen, T.; Bräuner-Osborne, H.; De Micheli, C. J. Med. Chem. 2008, 51, 2311-2315. doi:10.1021/jm701394a
121. Kaneko, T.; Yoshida, R. Bull. Chem. Soc. Jpn. 1962, 35, 1153-1155. doi:10.1246/bcsj.35.1153

122. Koglin, N.; Mueller, A.; Berndt, M.; Schmitt-Willich, H.; Toschi, L.; Stephens, A. W.; Gekeler, V.; Friebe, M.; Dinkelborg, L. M. Clin. Cancer Res. 2011, 17, 6000-6011. doi:10.1158/1078-0432.ccr-11-0687

123. Vidal-Cros, A.; Gaudry, M.; Marquet, A. J. Org. Chem. 1985, 50, 3163-3167. doi:10.1021/jo00217a029

124.Dinkelborg, L.; Friebe, M.; Krasikowa, R. N.; Belokon, Y.; Kuznetsova, O. F.; Graham, K.; Lehmann, L.; Berndt, M. [F-18]-labeled L-glutamic acid, [F-18]-labeled L-glutamine, derivatives thereof and use thereof and processes for their preparation. WO Patent WO 2008052788 A1 20080508, 2008.

125.Ducrocq, C.; Righini-Tapie, A.; Azerad, R.; Green, J. F.; Friedman, P. A.; Beaucourt, J.-P.; Rousseau, B. J. Chem. Soc., Perkin Trans. 1 1986, 1323-1328. doi:10.1039/p19860001323

\section{License and Terms}

This is an Open Access article under the terms of the Creative Commons Attribution License (http://creativecommons.org/licenses/by/4.0). Please note that the reuse, redistribution and reproduction in particular requires that the authors and source are credited.

The license is subject to the Beilstein Journal of Organic Chemistry terms and conditions:

(https://www.beilstein-journals.org/bjoc)

The definitive version of this article is the electronic one which can be found at: doi:10.3762/bjoc. 15.22 